\title{
Ownership Structure and the Cost of Corporate Borrowing*
}

\author{
Chen Lin \\ City University of Hong Kong \\ chenlin@cityu.edu.hk
}

Paul Malatesta

University of Washington

phmalat@u.washington.edu

\author{
Yue Ma \\ Lingnan University, Hong Kong \\ yuema@ln.edu.hk \\ Yuhai Xuan \\ Harvard Business School \\ yxuan@hbs.edu
}

Journal of Financial Economics, Forthcoming

\begin{abstract}
This article identifies an important channel through which excess control rights affect firm value. Using a new, hand-collected data set on corporate ownership and control of 3,468 firms in 22 countries during the 1996-2008 period, we find that the cost of debt financing is significantly higher for companies with a wider divergence between the largest ultimate owner's control rights and cash-flow rights and investigate factors that affect this relation. Our results suggest that potential tunneling and other moral hazard activities by large shareholders are facilitated by their excess control rights. These activities increase the monitoring costs and the credit risk faced by banks and, in turn, raise the cost of debt for the borrower.
\end{abstract}

\section{JEL classification codes: G21; G32; G34}

Keywords: Ownership structure; Excess control rights; Control-ownership wedge; Cost of debt; Bank loans

\footnotetext{
* We are grateful for helpful comments and suggestions to Ben Esty, Stuart Gilson, Paul Gompers, Rafael La Porta, Yair Listokin, Bill Schwert, Andrei Shleifer, Laura Starks, Jeremy Stein, Belen Villalonga, Michael Weisbach, Scott Weisbenner, and participants at the National Bureau of Economic Research (NBER) Summer Institute 2010 Law and Economics Workshop and the 2010 Financial Management Association International (FMA) Asian Conference. We thank Arbitor Ma, Pennie Wong and William Alden for help with data collection. Xuan acknowledges financial support from the Division of Research of the Harvard Business School.
} 


\section{Introduction}

The separation of ownership and control has long been viewed as the key to the analysis of the modern corporation, in which the classic agency conflict is set between shareholders and managers (Jensen and Meckling, 1976). It has been widely documented, however, that for most publicly traded firms around the world, ownership and control often vest with dominant shareholders. ${ }^{1}$ Moreover, the widespread use of pyramid ownership structures, dual-class shares, and cross-holdings typically enables large shareholders to exercise effective control over a company with a relatively small direct stake in the cash-flow rights. ${ }^{2}$ In such firms, the primary agency conflict is between large controlling shareholders and other investors, and the divergence between control rights and cash-flow rights creates a separation of ownership and control that aggravates these conflicts (Shleifer and Vishny, 1997).

Despite the widespread divergence between control and cash-flow rights (the “control-ownership wedge”), there is limited evidence on the financial implications of the wedge. Most studies focus on the relation between the control-ownership wedge and corporate valuation and find that the deviation between control rights and cash-flow rights is associated with lower firm value. ${ }^{3}$ Examining the link between the control-ownership wedge and firm value is one way to gauge the financial implications of the separation of

${ }^{1}$ La Porta et al. (1999) examine the ownership structure of large corporations in 27 wealthy economies and find that the firms are typically controlled by families or the state. Claessens et al. (2000) examine the separation of ownership and control for 2,980 corporations in nine East Asian countries and find that more than two-thirds of firms are controlled by a single large shareholder. Faccio and Lang (2002) study 5,232 corporations in 13 Western European countries and find similar results.

${ }^{2}$ For example, see La Porta et al. (1999), Claessens et al. (2000), Faccio and Lang (2002), and Lemmon and Lins (2003).

${ }^{3}$ For instance, Claessens et al. (2002) find that a one-standard-deviation increase in the excess control rights of the largest shareholder is associated with a 5\% decrease in firm value. Lemmon and Lins (2003) show that during the East Asian financial crisis, the stock returns of firms with separated control and cash-flow rights are $10 \%$ to $20 \%$ lower than those of other firms. In more recent studies, Laeven and Levine (2008) examine European firms with multiple large owners, and Gompers et al. (2010) study excess control rights for corporate insiders; both papers find similar patterns. 
ownership from control. Empirical estimation of this relation does not, however, identify how the wedge affects corporate values. Moreover, the extant literature on controlling shareholders and the consequences of ownership-control deviation typically takes on the perspective of equity holders. In this paper, we identify an important channel through which the divergence between control rights and cash-flow rights affects firm values. Specifically, we examine the impact of control rights-cash-flow rights divergence on firms' costs of borrowing.

Existing theories propose a straightforward connection between the control-ownership wedge of a firm's controlling shareholder and the firm's ability to raise external debt finance. Since large shareholders pursue their own interests, they may seek to expropriate other investors by diverting firm resources for their own use, transferring assets and profits out of companies, or committing funds to unprofitable projects that provide private benefits. Their incentives to engage in "tunneling" and other moral hazard activities are especially severe when their control rights are significantly in excess of their cash-flow rights because they have a greater ability to divert corporate resources for private benefits while at the same time bearing a smaller proportion of the financial consequence of such activities (Shleifer and Vishny, 1997; Johnson et al., 2000a). ${ }^{4}$ Many of these activities increase the probability of costly lower-tail outcomes, ${ }^{5}$ thus

4 As discussed in Johnson et al. (2000a, 2000b), the tunneling activities by controlling shareholders include various self-dealing transactions such as outright theft or fraud, expropriation of corporate opportunities, transfer pricing, asset sales or transfers to controlling shareholders or other corporations they control at favorable prices, loan guarantees using the firm's assets as collateral, etc. Johnson et al. (2000a) report a vivid example in the case of Barro, a Belgian company, with Flambo as its controlling shareholder. Minority shareholders of Barro sued Flambo, arguing that Flambo pledged Barro as collateral to guarantee Flambo's debt, forced Barro to acquire new shares of Flambo, withdrew money from Barro's accounts without repayment, diverted an important contract from Barro to Flambo, and used Barrow's utilities without payment. More examples can be found in Lemmon and Lins (2003).

5 See, for example, Gilson and Villalonga (2009), for a recent case on Adelphia Communications Corporation's bankruptcy, the eleventh largest bankruptcy case in history. The case highlights the potential expropriation of other investors by large, controlling shareholders such as founding families, who retain their controls through the dual-class share structure. 
increasing the expected costs associated with financial distress and bankruptcy. ${ }^{6}$ In addition, potential tunneling activities could impair the value of collateral, which in turn reduces the recovery rates in the event of a default. ${ }^{7}$ Since creditors incorporate expectations about financial distress costs and bankruptcy states into their lending decisions, a higher likelihood of negative outcomes results in higher financing costs. Moreover, Shleifer and Vishny (1997) argue that the problem of expropriation by controlling shareholders might become more severe when other investors are of a different type (e.g., creditor). Holding cash-flow rights constant, greater control rights (i.e., larger wedge) may provide extra risk-taking incentives to controlling shareholders because they may be able to use their effective control rights to divert the upside gains for private benefits while leaving the costs of failure to creditors. This potential effect aggravates the agency problem faced by the creditors and therefore, might also result in an increase in the cost of debt financing.

In this paper we examine the relation between the control-ownership wedge of a firm's largest shareholder and the firm's cost of bank debt using a new, hand-collected data set on corporate ownership and control of 3,468 firms in 22 Western European and East Asian countries during the period from 1996 to 2008 . We compute the cash-flow and voting rights of the ultimate largest owner of each firm and obtain detailed information on 13,331 bank loans made to the sample firms. We focus on the 22 countries in East Asia and West Europe because firms in these countries exhibit far more divergence between cash-flow rights and control rights than do U.S. firms and because

${ }^{6}$ These costs include direct bankruptcy costs, such as lawyers' charges, administrative and accounting fees, expert witness expenses, as well as indirect costs due to the potential loss of customers, suppliers, employees, and growth opportunities (Purnanandam, 2008). Indirect financial distress costs can be much greater than direct costs, amounting to $20 \%$ of firm value in some cases (Bris et al., 2006).

${ }^{7}$ As summarized by Friedman, Johnson, and Mitton (2003), many bankruptcy cases in countries such as Russia and Thailand were associated with complete looting by controlling shareholders so that creditors received almost nothing when the firms went out of business. Similar outcomes in Mexico were reported by La Porta, López-de-Silanes, and Zamarripa (2003). Akerlof and Romer (1993) provide a theoretical discussion. 
previous studies based on these countries show a significant value discount for firms with deviation between cash-flow rights and control rights. ${ }^{8}$ We focus on private credit agreements in the syndicated loan market (rather than, say, bond indentures) because this market has been the largest source of corporate financing worldwide over the past two decades (Ivashina, 2009). Indeed, Nini et al. (2009) report that roughly $80 \%$ of all public firms in the U.S. have private credit agreements in place, while only about $15 \%$ of those firms have public debt, and this difference is likely to be larger in countries like those in our sample that do not have well-developed public debt markets.

Our results indicate that the cost of debt financing is significantly higher at companies with a wider divergence between the largest owner's control rights and cash-flow rights. We define the control-ownership wedge as the difference between the control rights and cash-flow rights of the largest ultimate owner of the firm. Holding constant the cash-flow rights of the largest owner, and various borrower characteristics, loan characteristics, and macroeconomic factors, a one-standard-deviation increase in the control-ownership wedge increases the average loan spread by approximately $14 \%$ to $19 \%$, or 27 to 38 basis points, depending on the model specification. The effect of the wedge on loan spreads is statistically significant at the $1 \%$ level. The magnitude of the impact suggests that the effect of the separation of ownership and control on the cost of borrowing is economically significant, as well. ${ }^{9}$

The strong effect of ownership structure on loan spreads is robust to a series of different test specifications. It is consistent with the hypothesis that the separation of

${ }^{8}$ See, for example, Claessens et al. (2000), Claessens et al. (2002), Faccio and Lang (2002), Lemmon and Lins (2003), and Laeven and Levine (2008).

9 The magnitude of the loan spread increase is also economically significant compared to those identified in other studies on loan pricing. For example, Bharath et al. (2009) find that the cost of borrowing from a relationship lender is ten basis points lower than the cost of borrowing from a non-relationship lender. Chava et al. (2009) show that increasing the takeover vulnerability index of a firm by one standard deviation increases its average loan spread by 12 basis points. 
ownership from control increases the likelihood of tunneling and other moral hazard activities by the controlling shareholder and thereby increases the monitoring costs and the credit risk faced by banks. Lenders therefore raise the price of loans, and the borrower incurs a higher cost of debt as a result.

We also investigate the mechanisms through which the credit risk and the associated monitoring costs induced by the deviation between control rights and cash-flow rights at the borrowing firm can be mitigated. We examine factors that influence the relation between the control-ownership wedge and the loan spreads. The idea is that the effect of the control-ownership wedge on the cost of bank debt should be particularly strong in situations where the divergence between control rights and cash-flow rights is more likely to result in tunneling and other detrimental activities by the largest owner and thereby increase the credit risk. Conversely, the effect should be weakened by mechanisms that curb such activities or reduce the credit risk and the monitoring costs faced by lenders.

We focus on the following sets of factors: ownership identity, borrowing firm opaqueness, credit ratings, loan terms, legal rights (i.e., creditor and shareholder rights), and debt enforcement efficiency. We find that the effect of the control-ownership wedge on bank loan spreads is more pronounced if the borrowing firm is family-owned and if its CEO is also a member of the controlling family. The effect is also amplified for firms with higher degrees of informational opacity. It is greater for small firms, firms without debt ratings, firms that are not included in a national major stock index, and those with relatively meager analyst coverage. The effect is also greater for firms with lower credit ratings. Furthermore, the effect varies with loan type and maturity, being larger for bullet loans and increasing with loan maturity. On the other hand, the presence of collateral and loan covenants appears to mitigate the potential conflicts between large shareholders and creditors and weakens the link between the control-ownership wedge and loan spreads. Similarly, our results suggest that laws and institutions that constrain self-dealing and asset 
substitution activities moderate the relation between excess control rights and the cost of bank debt. Strong shareholder rights tend to reduce self-dealing and tunneling activities (Djankov et al., 2008b) while strong creditor rights grant more power to creditors in bankruptcy and deter risk-shifting behaviors (Qian and Strahan, 2007; Houston et al., 2010). We find that stronger shareholder rights (anti-self-dealing) and creditor rights and more efficient debt enforcement (Djankov et al., 2008a) all have a direct negative impact on loan spreads. It is more interesting, though, that the interactions between the legal rights and the control-ownership wedge imply that stronger protection of shareholder and creditor rights and more efficient debt enforcement reduce the effect of excess control rights on loan spreads.

Finally, we use the global banking crisis database compiled by Honohan and Laeven (2005) to examine the relation between ownership structure and the cost of bank debt during financial crises. As Lemmon and Lins (2003) point out, financial crises represent a relatively exogenous shock, at least with respect to any individual firm, that significantly lowers the available return on investment of firms in the affected countries. Holding ownership structure constant, this shock to returns lowers the marginal cost to controlling shareholders of diverting resources away from profitable investment projects and increases the expected level of expropriation (Johnson et al., 2000b). Therefore, the control-ownership wedge should have a larger effect on the cost of debt financing during crisis periods. Indeed, we find that this effect is particularly prominent when a country experiences a banking crisis, especially when the country has poor protections for shareholder rights and creditor rights.

The aforementioned analyses focus on the tunneling perspective of the controlling shareholders. However, empirical evidence also suggests "propping" activities by controlling shareholders within affiliated firms (Mitton, 2002; Friedman, Johnson, and Mitton, 2003). As Friedman, Johnson, and Mitton (2003) point out, the controlling 
shareholders have incentives to transfer funds to a specific firm from other affiliates in a business group in order to preserve their options to expropriate the future profits of the firm. This kind of wealth transfer within business groups is more likely to occur from the firms in which the controlling shareholders have low ownership stakes to the firms in which they have high ownership stakes (Bertrand, Mehta, and Mullainathan, 2002). For example, assume that a controlling shareholder owns $b \%$ of firm $\mathrm{B}$, which in turn owns $c \%$ of firm C. The controlling shareholder may expropriate firm $C$ to prop up firm B. In such cases, looting may benefit B's creditors while hurting C's creditors. ${ }^{10}$ To assess this potential propping effect, we keep track of the borrowing firm's position in the ownership chain and determine the value of the assets that lie underneath the firm that could potentially be used to prop it up. Our results indicate that, consistent with the propping effect, the more assets that could potentially be used to prop up a borrowing firm, the lower is its cost of debt financing. More important, we find that the borrowing firm's potential for being propped up attenuates the effect of the control-ownership wedge on loan spreads. In other words, the effect of the control-ownership wedge on the cost of bank debt is less pronounced in firms with high propping potentials.

Another potential problem for interpreting our results is the issue of endogeneity. Since loan spreads are largely set by the creditors and by competitive forces in the market for loanable funds, it is not very likely that the loan spreads would affect corporate ownership and control. However, borrowers with certain ownership structures might have other firm-specific characteristics unaccounted for in our study that affect both the control-ownership separation and the cost of borrowing. The joint determination of ownership structure and an unobserved or uncontrolled factor could potentially bias our

${ }^{10}$ It is not always true that lending to firm B is safer than lending to firm C. For instance, suppose that firm $\mathrm{B}$ is a holding company whose sole income is the $\$ 10$ dividend that it receives from $\mathrm{C}$ and that firm B needs to pay its creditors $\$ 10$ to stay current on its debt. Then C's creditors might be safer than B's because if the controlling shareholders steal too much from C, it would cause B to go bankrupt. The average effect is an empirical question that we will explore in this paper. 
results. The interaction results from sharper tests focusing on factors (e.g., the exogenous crisis shock) that influence the relation between the control-ownership wedge and the borrowing cost help to alleviate this concern because they are less susceptible to the endogeneity biases.

To further ameliorate the problem, we use two strategies. In the spirit of Laeven and Levine (2009), we use the initial industry average difference between control rights and cash-flow rights and the initial industry average cash-flow rights for each borrower as instruments for the borrower's control-ownership wedge and largest-owner cash-flow rights, respectively. The industry averages are country-specific and are measured in the year prior to the start of our sample. Thus, we avoid the simultaneity problem. The industry average ownership structure is correlated with borrowers' ownership structures but is unlikely to directly influence the loan spreads of any particular firm except through the borrower's control-ownership wedge and largest-owner cash-flow rights. Furthermore, industry-level ownership structure measures are very stable over time in each country, and we control for macroeconomic factors as well as industry fixed effects, alleviating the concern that some country-level and industry-level factors might affect an entire industry's ownership structure and cost of debt. If the endogeneity problem is specific to firms, but not to industries or locations, then netting out this firm-specific component yields a wedge measure that only depends on the underlying characteristics inherent to particular industries or locations (Lin et al., 2010). We examine also the effect of a change in the borrower's ownership structure on the change in loan spreads. Focusing on changes accounts for any time-invariant common unobservable or omitted firm-specific characteristics that might affect both the ownership structure and the cost of bank debt. Our results remain economically and statistically strong under either the instrumental variables approach or the change regressions approach. Though it is 
impossible to completely eliminate endogeneity concerns, endogeneity seems unlikely to account for or to bias our empirical findings.

Taken together, our results suggest that tunneling and other moral hazard activities by large shareholders are facilitated by the divergence between control rights and cash-flow rights. These activities, on average, increase monitoring costs and credit risks faced by banks and, in turn, raise the cost to borrowers of bank debt. The paper contributes to a number of related literatures. With regard to the ownership literature, our findings show that the divergence between control rights and cash-flow rights has a first-order effect on firm debt financing and shed direct light on a channel through which such divergence affects firm value. Masulis et al. (2009) examine the divergence for insiders in a sample of U.S. dual-class firms and find that, as the deviation between control rights and cash-flow rights of corporate insiders widens, corporate cash holdings are worth less to outside shareholders, and acquisitions and capital expenditures are less likely to be value-creating, while CEOs receive higher compensations. Our study is among the first to focus on the creditors' perspective and to examine creditors' evaluation of the separation of ownership from control. Therefore, our paper adds to the bank loan literature (e.g., Graham et al., 2008; Bharath et al., 2009; Ivashina, 2009) by showing that ownership structure is an important determinant of loan pricing. Finally, our results also contribute to a small but growing line of research on how laws and institutions affect bank lending activities (e.g., Esty and Megginson, 2003; Qian and Strahan, 2007; Houston et al., 2010).

The remainder of the paper proceeds as follows. Section 2 describes the data and the construction of the ownership variables. Section 3 presents the empirical results. Section 4 concludes.

\section{Data and variables}




\subsection{Sample construction}

We begin our sample construction process with the combined data sets used in Claessens et al. (2000) for nine East Asian economies, and in Faccio and Lang (2002) for 13 Western European countries. These two data sets provide the ultimate ownership of the corporations in 22 Western European and East Asian countries for the period from 1996 to $1999 .^{11}$ We then check the Dealscan database for available loan contract information in the 22 countries during the period from 1996 to 2008. Our manual data-gathering process starts with a sample of 13,331 loan contracts collected from Dealscan for which we have firm ownership information from Factset, OSIRIS, or Worldscope. We then use the Factset, OSIRIS, and Worldscope global ownership databases to track the ownership chains of each borrower and hand-collect information on the borrower's ultimate ownership and control. We start our search in OSIRIS. For ownership information not available in OSIRIS, we search Factset and Worldscope. Following La Porta et al. (1999) and Laeven and Levine (2008), we define a shareholder as "large" if its direct and indirect voting rights sum to $10 \%$ or more. Our results are robust to using different thresholds, such as $20 \%$. If no shareholder holds $10 \%$ or more of the voting rights, the firm is classified as widely held. While direct ownership involves shares held under the shareholder's name, indirect ownership involves shares held by entities that the ultimate shareholder controls (Laeven and Levine, 2008). Because the large shareholders of corporations are often corporations themselves, we identify the large shareholders in these corporations by tracing backward the "knotty"

${ }^{11}$ The 13 Western European countries are Austria, Belgium, Finland, France, Germany, Ireland, Italy, Norway, Portugal, Spain, Sweden, Switzerland, and the United Kingdom. The nine East Asian countries (regions) include Hong Kong, Indonesia, Japan, Malaysia, Philippines, Singapore, South Korea, Taiwan, and Thailand. 
control chains through numerous corporations to identify the ultimate controlling shareholders. This yields a firm-level ownership data set for 3,468 individual firms in 22 countries over 1996 to 2008. We obtain and calculate additional information about these firms from Worldscope on firm characteristics, such as firm size, profitability, $Q$, tangibility, cash-flow volatility, etc. ${ }^{12}$

\subsection{Computation of cash-flow rights and control rights}

To study the separation of ownership and control, we require data on both cash-flow rights and control rights, which we calculate using the complete chain of corporate ownership. We construct the ultimate ownership and control measures in a manner consistent with the previous ownership literature (e.g., Claessens et al., 2000; Faccio and Lang, 2002; Laeven and Levine, 2008). We describe briefly the computation below.

Direct ownership is defined as direct cash-flow rights. To compute indirect cash-flow rights, we multiply the cash-flow rights along the ownership chain until we reach the ultimate owner of the firm. For example, if firm A owns fraction $b$ of firm B, and firm B in turn owns fraction $c$ of firm $\mathrm{C}$, and both $b$ and $c$ are greater than the $10 \%$ threshold, then firm A's indirect cash-flow rights in firm C is the product of $b$ and $c$. We add direct and indirect cash-flow rights to arrive at the aggregate cash-flow rights. Similarly, we add direct and indirect control rights to arrive at the aggregate control rights. Control rights can differ from cash-flow rights due to pyramidal structures, dual-class

12 The 1996-1999 ownership data are from Claessens et al. (2000) and Faccio and Lang (2002), where ownership for each firm is computed at some point during the period from 1996 to 1999 . We augment the ownership data for the remaining years (2000-2008). To make the hand-collection workloads manageable, we follow the previous studies and update the ownership information in three block periods: 2000-2003, 2004-2006, and 2007-2008. We chose years 2002, 2005, and 2007 as the base years to collect the firm ownership information. If we cannot find the firm ownership in these years, we search the other years in the block period. As La Porta et al. (1999) and Faccio and Lang (2002) point out, ownership structures tend to be stable over short time periods. 
shares, and multiple control chains. In the chain of control, control rights are measured by the weakest link. In the above example, firm A's control rights in firm $\mathrm{C}$ is $\min (b$, c). ${ }^{13}$ To determine effective control at intermediate levels and at the ultimate level, we follow the previous studies (e.g., La Porta et al., 1999; Faccio and Lang, 2002) and use 10\% as the threshold above which we assume that the shareholder has effective control over the intermediate and final corporations. If no owner of the firm has $10 \%$ of the voting rights, the firm is classified as widely held. The largest ultimate owner is defined as the ultimate owner that has the greatest control rights.

Following the above procedure, we compute the cash-flow rights and control rights measures for our sample firms. Our key measure, the control-ownership wedge, captures the deviation between control rights and cash-flow rights. It is defined as the difference between the control rights and cash-flow rights of the largest ultimate owner of the firm. This definition follows La Porta et al. (1999), Claessens et al. (2000), Claessens et al. (2002), Faccio and Lang (2002), and Laeven and Levine (2008), among others. Our results are robust to using the ratio of control to cash-flow rights to compute the wedge instead of the difference between the rights.

\subsection{Loan spreads}

Our measure for loan pricing is from Dealscan, which allows us to identify deal-level data in each year, and to observe various terms of the loans at origination, including the interest rate, the maturity of the loan, the size of the loan, and the purpose of the loan.

13 Claessens et al. (2002) provide a simple numerical example. Suppose that a family owns $11 \%$ of the stock of publicly traded firm A, which in turn has $21 \%$ of the stock of firm B. Then the family owns about $2 \%(11 \% \times 21 \%)$ of the cash-flow rights of firm B, the product of the two ownership stakes along the chain, and $11 \%$ of the control rights in firm $\mathrm{B}$, the weakest link in the chain of control rights. See Claessens et al. (2000) and Faccio and Lang (2002) for many more complex examples and detailed discussions. 
We use the all-in-spread drawn as the measure of the interest rate charged on a loan facility. This measures the basis point spread over the London Interbank Offered Rate (LIBOR) or LIBOR equivalent on a loan plus associated loan origination fees. Thus, it is an all-inclusive measure of loan price (Bharath et al., 2009). To mitigate the effect of skewness in the data, we use the natural logarithm of the loan spread (Graham et al., 2008; Chava et al., 2009).

\subsection{Control variables}

To assess the impact of the control-ownership wedge on loan spreads, we control for other factors that might affect loan pricing. These factors include borrower characteristics, loan characteristics, macroeconomic factors, as well as borrower industry and year fixed effects. The reasons for including these control variables in loan spread models are relatively well-known, so we provide only a brief discussion below. Detailed definitions for all the variables used in the paper are provided in Table 1.

[Insert Table 1 here]

We control for borrower firm characteristics. Firm characteristics that we control for include firm size, leverage, $Q$, profitability, asset tangibility, and cash-flow volatility. We expect large firms to suffer less from information asymmetries in the credit markets than small firms. Larger firms have longer track records and are followed by more financial analysts. As a result, larger firms should command lower loan spreads, other things equal. Profitable, low-leverage firms and firms with stable cash flows have lower probabilities of default and are thus also expected to have lower loan spreads. In addition, all else equal, firms with more tangible assets may offer higher recovery values in default states, which may imply lower spreads on their loans. Predictions are less clear-cut for the market-to-book ratio or $Q$ (Graham et al., 2008). It is possible that the 
market-to-book ratio proxies for risk or, alternatively, that it proxies for additional value (over liquidation) that is left to creditors in distress states.

We also control for loan-specific characteristics that prior literature has shown to affect spreads (Graham et al., 2008). We control for the natural log of loan size because there may be economies of scale in bank lending. If so, the loan spread would be negatively related to loan size. We further control for loan maturity because banks might face greater uncertainty and higher credit risk in loans carrying relatively long maturities. Loans that include contingent performance-based pricing may differ from loans without such clauses. To control for this possibility, we use a dummy variable that takes the value of one if there is performance-based pricing. In addition, we use dummy variables to control for the likelihood that different types of loans (term loans and revolvers) and loans granted for different purposes (working capital or general corporate purpose, refinancing, acquisition, commercial paper backup, and others) might carry different risks and may therefore be priced in different ways.

Because data are unavailable, some other potentially relevant firm or loan characteristics are not directly observable. For instance, an important determinant of loss given default is subordination, which defines inter-creditor priority in the event of bankruptcy (Carleton and Delaney, 2009). Structural subordination specifies that the creditors of the parent company can only get paid after the creditors of the operating subsidiary have been made whole. As a result, creditors might deem it safer to lend to operating subsidiaries than to the parent company and might stipulate limitations on subsidiary borrowing or require upstream guarantees to reduce the impact of structural subordination (Carleton and Delaney, 2009). Because of data limitations in our source countries, the subordination information is not readily available. ${ }^{14}$ To control for these

${ }^{14}$ Another piece of information that is of interest is insider ownership. Higher insider ownership might imply better corporate governance and deter moral hazard activities and thus, lower a firm's borrowing cost. Unfortunately, insider ownership information is not available in our cross-country data. Moreover, the interpretation of the effect of insider ownership on the cost of corporate borrowing could be 
potential factors and isolate the impact of the control-ownership wedge on the cost of debt financing, we include the borrower's Standard \& Poor's (S\&P) credit rating in the model. In addition, S\&P ratings also control for creditworthiness. Compared to firms with low credit ratings or firms without credit ratings, firms with high ratings may obtain more favorable loan terms such as lower interest rates (Qian and Strahan, 2007). As Anthony and Puccia (2005) suggest, S\&P explicitly states that they take into consideration the variations in structural subordination in assigning ratings. Carleton and Delaney (2009) present an intuitive case regarding structural subordination using the Wendy's/Arby's Group as an example. The debt of the subsidiaries of the Wendy's/Arby's Group was rated $\mathrm{B}$ by S\&P while the debt of the holding company was rated B-.

We convert the S\&P credit ratings into an index from one to six, with one assigned to the highest AAA rating. About 38\% of the sample observations do not have a credit rating. We follow previous studies (e.g., Qian and Strahan, 2007) and assign a value of seven to the rating of these missing observations to avoid losing them. To identify these observations, we also separately include in the model a dummy variable that takes the value one when the firm's credit rating is missing.

Macroeconomic factors and legal environments may also affect loan pricing. Following previous studies (e.g., Esty and Megginson, 2003; Qian and Strahan, 2007; Bae and Goyal, 2009), we control for factors such as natural log of gross domestic product (GDP) per capita (proxy for economic development), sovereign risk rating (proxy for country risk), and private credit to GDP (proxy for financial development). Furthermore, Qian and Strahan (2007) find that stronger creditor rights reduce loan spreads. We therefore control for creditor rights using the creditor rights index of La Porta et al. (1998) and Djankov et al. (2007). ${ }^{15}$ The aggregate creditor rights index ranges from zero to

clouded by the possibility that undiversified owners may avoid risky projects.

15 This index consists of four components: (1) whether there are restrictions imposed, such as creditors' consent, when a debtor files for reorganization (Restrictions on reorganization); (2) whether 
four, with higher values indicating stronger creditor rights. Table 2 provides summary statistics for our sample.

[Insert Table 2 here]

\section{Results}

\subsection{The effect of the separation of ownership and control on loan pricing}

In this section we examine the impact of the separation of ownership and control on loan pricing using multivariate ordinary least squares (OLS) regressions. The main empirical model we estimate is as follows:

$\log ($ loan spread $)=f($ Wedge measure, Borrower characteristics, Loan characteristics, Macroeconomic factors, Industry and time effects).

In Eq. (1), the dependent variable is the natural logarithm of the loan spread for a single bank loan. All of the results in the paper are qualitatively similar if we use the loan spread instead of its natural logarithm as the dependent variable. The key independent variable of interest is a proxy for the deviation between control rights and cash-flow rights, the control-ownership wedge. As detailed in the previous section, other independent variables include the cash-flow rights of the firm's largest ultimate owner and controls for other borrower characteristics, loan characteristics, macroeconomic factors, as well as borrower industry and year fixed effects.

[Insert Table 3 here]

secured creditors have the ability to seize collateral after the petition for reorganization is approved (No automatic stay); (3) whether secured creditors are ranked first in the distribution of proceeds from liquidation as opposed to other creditors such as employees (Secured creditor paid first); and (4) whether an administrator, rather than the incumbent management, is in control of and responsible for running the business during the reorganization (No management stay). A value of one is added to the index when a country's laws and regulations provide each of these powers to secured creditors to arrive at the aggregate creditor rights index. Djankov et al. (2007) extend the creditor rights data set to include annual observation across 129 countries over the period from 1978 to 2003. 
Table 3 reports the regression results. In columns 1 through 4, we use two dummy variables to capture the difference between control rights and cash-flow rights. The High- (Low-) wedge dummy is an indicator variable that equals one if the share of control rights of the firm's largest ultimate owner exceeds the share of cash-flow rights and if this difference is higher than (less than or equal to) the median difference in firms where the control-ownership wedge is greater than zero. These dummy variables separate the sample firms into three groups according to their control-ownership wedge: no-wedge firms, low-wedge firms, and high-wedge firms, and the omitted group is the no-wedge group. In columns 5 through 8, we use the continuous variable, control-ownership wedge, directly as the key independent variable instead.

For each set of regressions we run four specifications. The first controls for a set of borrower characteristics only, including the cash-flow rights of the borrower's largest ultimate owner. The second adds controls for loan characteristics as well as industry and year fixed effects. The third adds controls for macroeconomic factors and the fourth adds borrower credit ratings and $Q$ as additional controls. As discussed previously, we include credit ratings to control for borrower creditworthiness as well as unobserved firm and loan characteristics such as structural subordination. $\quad Q$ is used to proxy for the firm's growth potential. Adding these controls might, on the other hand, incur some costs. If rating agencies are aware that ownership structure affects the creditworthiness of the firm, credit ratings may already partially factor in the complexity of the borrower's ownership structure. A similar argument applies to the market's perception and the market value (and thus $Q$ ) of the firm. Nevertheless, these effects would work against finding a significant impact of the wedge on the cost of borrowing. Therefore, the estimates based on the models with credit ratings and $Q$ as additional controls can be viewed as conservative estimates of the effect of the control-ownership wedge on loan pricing. All 
p-values reported are based on standard errors that are corrected for heteroskedasticity and are clustered at the firm level.

Across all specifications, we see that the cash-flow rights of the borrower's largest ultimate owner are negatively related to loan spreads. A one-standard-deviation increase in cash-flow rights reduces the average loan spread by $8.9 \%$ to $10.7 \%$ (or 17 to 21 basis points), everything else equal. ${ }^{16}$ Consistent with the literature, we also find that larger borrower firm size, better debt ratings, higher profitability, and lower leverage tend to be associated with significantly lower bank loan spreads. Holding the cash-flow rights and other factors constant, however, the wedge between control rights and cash-flow rights is significantly positively related to the cost of bank debt. Estimates from columns 1 to 4 indicate that the average spread on bank loans in firms with a high control-ownership wedge is significantly greater than the average loan spread for firms with a low control-ownership wedge which, in turn, significantly exceeds the average spread for firms with no deviation between control rights and cash-flow rights. The difference between the coefficient estimates on the High-wedge and Low-wedge dummies is significantly different from zero at the $1 \%$ level in columns 1 to 4 of Table 3 . Similarly, in columns 5 to 8, the coefficients on the continuous measure of control-ownership wedge are all positive and highly significant at the $1 \%$ level. $^{17}$

A one-standard-deviation increase in the control-ownership wedge increases the average loan spread by approximately 18\%, or 35 basis points, ceteris paribus (column 7). Hence, the effect of the separation of ownership and control on the cost of borrowing is economically as well as statistically significant. After controlling for credit ratings and $Q$

16 Since the dependant variable of the regression, loan spreads, is in logarithm, the coefficient on an independent variable can be interpreted as the percentage change, or the growth rate, in loan spreads as the independent variable increases by one unit.

17 For the rest of the paper, we focus on the continuous measure of control-ownership wedge in our empirical analysis. All of our results are qualitatively unchanged if we use the wedge dummies. 
(column 8), which are both significant at the $10 \%$ level, the effect of a one-standard-deviation increase in the wedge drops to $14 \%$, or 27 basis points. This suggests that borrower credit ratings and $Q$ partially capture the effects of the borrower's ownership structure. $^{18}$ Despite this, the coefficient on the control-ownership wedge remains significant at the $1 \%$ level. ${ }^{19}$ The effect of the control-ownership wedge is also economically significant compared to the effect on loan pricing of other factors documented in the literature. For example, Bharath et al. (2009) find that the cost of borrowing from a relationship lender is ten basis points lower than the cost of borrowing from a non-relationship lender. Qian and Strahan (2007) show that increasing a country’s creditor rights index by one standard deviation reduces the average loan spread in the country by $10 \%$.

\subsection{Endogeneity of ownership structure and other robustness tests}

One concern about our results on the relation between the control-ownership separation and bank loan pricing is the issue of endogeneity. Borrowers with certain ownership structures might have other firm-specific characteristics unaccounted for in our model that affect both the control-ownership separation and the cost of borrowing. The joint determination of the ownership structure and an unobserved or uncontrolled factor could potentially bias the results. Although it is extremely difficult to completely solve the endogeneity problem, in this section, we attempt to address this issue in two ways. First, we use instrumental variables for each borrower's ownership structure. Second, we

${ }^{18}$ In unreported results, we regress S\&P firm credit rating on the control-ownership wedge and find a significant relation. The higher is the wedge, the worse is the credit rating. This suggests that rating agencies have taken into account corporate governance considerations when rating issuers.

19 In the remainder of the paper, we use the full set of controls including the credit ratings and $Q$. The results are highly robust without these controls. 
estimate change regressions by examining the effect of changes in borrowers' ownership structures on changes in loan spreads. In addition, we show that our results are robust to various alternative test specifications.

\subsubsection{Instrumental variables estimation}

To address the concern of endogeneity, we first employ the instrumental variables approach. In the spirit of Laeven and Levine (2009), we use the initial industry average difference between control rights and cash-flow rights and the initial industry average cash-flow rights for each borrower as instruments for the borrower's control-ownership wedge and largest-owner cash-flow rights, respectively. ${ }^{20}$ The industry averages are country-specific and are measured in the year prior to the start of our sample. The industry average ownership structure is correlated with a borrower's ownership structure (Laeven and Levine, 2009) but is unlikely to directly influence the loan spreads of the particular firm except through the borrower's control-ownership wedge and largest-owner cash-flow rights. Furthermore, the industry-level ownership structure measures are very stable over time in each country, and we control for macroeconomic factors as well as industry fixed effects. This alleviates the concern that some country-level and industry-level factors might affect an entire industry's ownership structure and cost of debt.

\section{[Insert Table 4 here]}

Table 4 reports the regression results using instrumental variables, with log loan spread as the dependent variable. The F-statistics in the first stage (unreported but

${ }^{20}$ Laeven and Levine (2009) use the average cash-flow rights of other banks in the country as an instrument for a bank's ownership structure to study the link between bank risk and bank ownership and governance. We thank Mara Faccio for providing the data for the initial average control-ownership wedge measure for each industry in each country in our sample. 
available upon request) indicate that the coefficients on the instruments are significantly different from zero at the $1 \%$ level. From the estimates in Table 4, we see that the coefficients on the control-ownership wedge in the instrumental variable regressions are positive and significant at the $1 \%$ level, with even larger magnitudes than the coefficient estimates from the OLS regressions. The coefficients on the cash-flow rights of the largest owner remain negative and significant. These results are consistent with our earlier analyses and support the view that the separation of ownership and control increases the cost of bank loans for borrowers. The effect of ownership structure on loan spreads remains and is, in fact, strengthened after addressing the potential endogeneity problem.

\subsubsection{Change regressions}

We next examine the effect of changes in borrower ownership structures on changes in loan spreads. Focusing on changes accounts for time-invariant common unobservable or omitted firm-specific characteristics that might affect both the ownership structure and the cost of bank debt.

To construct the sample for the change regressions and compute the changes, we require that a borrower has at least two bank loans in our sample, each in a different year. If a borrower has more than one loan in a given year, we use the first loan observation in that year to compute the changes. The results are qualitatively similar if we randomly select a loan in a given year instead of choosing the first. Since the borrower ownership structure tends to be stable over time as mentioned earlier, we drop differenced observations if there is no change in the borrower's control-ownership wedge between two periods. ${ }^{21}$

${ }^{21}$ This methodology follows in the fashion of Chava et al. (2009), who use change regression analyses to study the effect of corporate takeover defenses on loan costs. 
[Insert Table 5 here]

We present the results of the change regressions in Table 5, where the dependent variable is the change in log loan spreads and the key independent variable is the change in the control-ownership wedge for the borrower. We control for the change in the cash-flow rights of the borrower's largest owner, as well as changes in various borrower characteristics, loan characteristics, and macroeconomic factors. The results in Table 5 indicate that, for a given firm, the change in the cash-flow rights of a borrower's largest owner is negatively related to the change in the firm's loan spreads, everything else equal. The change in the borrower's control-ownership wedge has the exact opposite effect. An increase in the wedge is associated with a significant increase in the loan spread. These results further confirm the findings from the preceding regression analyses.

\subsubsection{Other robustness tests}

In this section we check the robustness of our results by changing various aspects of the test specification. The results of these robustness tests are not tabulated in the paper but they are available upon request.

In one set of tests we use an alternative definition of excess control rights. Instead of the difference between control rights and cash-flow rights, we examine the ratio of the fraction of voting rights controlled by the largest owner to the fraction of cash-flow rights controlled by the largest owner. To address the issue of potential outliers driving the results we also re-estimate our regressions in two ways. We eliminate extreme values by winsorizing at the $0.5 \%$ level and by using median regressions. We note also that each observation in our base analysis represents a single loan but that a borrower can have multiple loans in a given year, with several loans belonging to the same deal package. To address the possibility that the loan terms for these facilities might not be negotiated 
independently, we aggregate multiple loans in two ways to form new observations and perform our analyses on these new units. Specifically, we compute the loan size-weighted averages of all the loan terms at the deal level or in any given year for a given firm and repeat the regressions using deal-level observations or firm-year observations. In still other tests we eliminate amendments of existing facilities, dropping observations where the loan is identified in the Dealscan database as an amended facility. Recall that we include loan maturity as a control variable in our regressions of loan spreads on ownership structure. To address the potential endogenous determination of spread and maturity in a loan contract, we estimate two-stage least-square regressions using the asset maturity for the borrower as an instrument for the loan maturity. ${ }^{22}$ Finally, instead of doing change regressions, we include firm fixed effects in all our regressions to explore within-firm differences. In all of the above robustness tests, our results remain statistically and economically significant. In every case, the estimated coefficients are similar in magnitudes to those reported in Table 3.

Overall, our results from the multivariate regression analyses indicate that the deviation between control rights and cash-flow rights is significantly positively related to loan spreads. The link between the control-ownership wedge and loan spreads remains economically and statistically significant even after controlling for various borrower characteristics, loan characteristics, macroeconomic factors, as well as industry and time effects, correcting for potential endogeneity problems, and using a series of different test specifications. $^{23}$ The strong effect of ownership structure on loan spreads is consistent

${ }^{22}$ See, for example, Graham et al. (2008) and Bharath et al. (2009) for discussions of the validity of using asset maturity as an instrument for debt maturity. Asset maturity is calculated according to Barclay and Smith (1995) and Barclay et al. (2003) as the book value-weighted average of maturity of current assets and net property, plant, and equipment.

${ }^{23}$ These results are consistent with those reported by Aslan and Kumar (2009), who use simultaneous equations to address the joint determination of loan pricing, loan maturity, and the number of participants in the syndication in the study of controlling shareholders and loan contracts. Billett and Liu (2008), who study the relation between managerial excess control rights and the cost of debt in a sample of U.S. dual-class firms, also find consistent results. 
with the hypothesis that the separation of ownership and control increases the likelihood of tunneling and other potential moral hazard activities by the largest owner and thereby increases the monitoring costs and the credit risk faced by banks. Lenders therefore raise the price of loans, and borrowers incur higher debt costs as a result.

\subsection{Factors influencing the link between ownership structure and borrowing cost}

In this section, we seek to elucidate the mechanisms through which the credit risk and the associated monitoring costs induced by the divergence between control rights and cash-flow rights at the borrowing firm can be affected. Specifically, we examine factors that influence the relation between the control-ownership wedge and the loan spreads. The idea is that the effect of the control-ownership wedge on the cost of bank debt should be particularly strong in situations where the deviation between control rights and cash-flow rights is more likely to result in tunneling and other potential moral hazard activities by the largest owner and thereby increase the credit risk. Conversely, the effect should be weakened by mechanisms that help to curb such activities or to reduce the credit risk and the monitoring costs faced by lenders. We focus on the following sets of factors: ownership identity, borrowing firm opaqueness, credit rating, propping potential, loan terms, legal rights (i.e., creditor and shareholder rights), and debt enforcement efficiency. We also examine the relation between ownership structure and the cost of bank debt during financial crises.

\subsubsection{Ownership identity}

Previous studies show that large shareholdings in general, and the separation of ownership and control in particular, are often associated with family ownership (e.g., La 
Porta et al., 1999; Claessens et al., 2000; Faccio and Lang, 2002). In our sample, 45\% of the firms are ultimately controlled by families. As Shleifer and Vishny (1997) note, large shareholders may have incentives to use their controlling positions in firms to expropriate wealth from other investors. These incentives, however, may vary across different types of large owners. As Villalonga and Amit (2006) point out, if the large shareholder is an institution such as a bank, an investment fund, or a widely held corporation, the private benefits of control are diluted among many independent owners. As a result, the large shareholder's tunneling incentives might be weak. If, on the other hand, the large shareholder is an individual or a family, it might have stronger incentives for expropriation. Therefore, we categorize the largest ultimate shareholders into families, the state, or widely held corporations and financial institutions, and examine whether our results are more prominent for particular types of ultimate owners. We investigate this matter by including ownership identity dummies (family, state) and their interactions with the control-ownership wedge in our baseline model. The results of these tests are presented in Table 6.

\section{[Insert Table 6 here]}

As can be seen from the first two columns of Table 6, our results show that the coefficients of the wedge-family interaction terms are positive and statistically significant. These estimates indicate that the positive effect of the wedge on loan spreads is greater for firms with families as controlling shareholders. Consistent with the literature (Villalonga and Amit, 2006), these findings imply that tunneling risks are higher in family-controlled firms.

In addition, families often limit executive management positions to family members (Villalonga and Amit, 2006) to further strengthen their control over the firm, and in such firms, value discounts are more severe (Claessens et al., 2002). We therefore hand-collect information on the CEO-family connection from company filings and 
executive biographies. We create a dummy variable, Family CEO, which equals one if a firm is family-controlled and the CEO is a family member of the controlling family. We then include this variable and its interaction with the control-ownership wedge in our model. ${ }^{24}$ The coefficients for Wedge, Family, Family CEO, and the two interaction terms are all positive and statistically significant. Hence, the link between the control-ownership wedge and the cost of bank loans is stronger for family firms, especially if the firm also has a family-related CEO. To appreciate the economic significance of our findings, consider the set of coefficients reported under column 3 of Table 6. These estimates imply that increasing the control-ownership wedge by one standard deviation increases loan spreads by $16.2 \%$ for firms controlled by widely held corporations (the benchmark group), and increases loan spread by $27.4 \%$ for family-controlled firms with family-connected CEOs. In other words, a one-standard-deviation increase in the control-ownership wedge increases the loan spread of a family-controlled firm with a family-related CEO by 21.9 basis points more than a similar increase in wedge for a firm controlled by widely held corporations. In column 4, we add the dummy indicating state control and its interaction term with the control-ownership wedge. The loan spreads-wedge sensitivity might be lower in state-controlled firms because of their lower default risks due to potential bailouts by the state and lower tunneling incentives. Our empirical results show that loan spreads are indeed less sensitive to the wedge in state-controlled firms, as indicated by the negative interactive term between State and Wedge.

\subsection{2. $\quad$ Borrowing firm informational opacity}

\footnotetext{
24 Note that the dummy Family always equals one if Family CEO equals one. Therefore, we do not need to include Family*Family CEO or Family*Family CEO*Wedge in our regressions once Family CEO and Family $C E O^{*}$ Wedge are included.
} 
Holding ownership structure constant, firm informational opacity might lower the marginal costs to controlling shareholders of diverting resources away from the company and engaging in other moral hazard activities for private benefits. As a result, informational opacity of the borrowing firm would increase the likelihood and the expected level of expropriation and therefore strengthen the relation between the control-ownership wedge and the firm's borrowing cost. To test this conjecture, we add the interaction between informational opacity measures and the wedge to the baseline model. Following Bharath et al. (2009), we use four different measures of informational opacity in our tests: firm size (i.e., natural log of assets), whether the firm has a debt rating, inclusion in a national major stock index, and the number of analysts following the firm. The intuitions for these informational opacity measures are well-known. We provide here only a brief discussion. Smaller firms and firms without credit ratings tend to have less publicly available information, while firms included in the national major stock indexes and covered by more stock analysts are likely to be more informationally transparent as monitoring by the credit rating agencies and coverage by analysts reduces informational asymmetries (Bharath et al., 2009). We re-estimate our baseline model including these informational opacity proxies and their interactions with the control-ownership wedge and report the results in Table 7.

[Insert Table 7 here]

As can be seen from the table, loan spreads are less sensitive to the wedge for larger firms, firms included in the national major stock indexes, and firms followed by more stock analysts, as indicated by the negative and statistically significant coefficients of the interaction terms. On the other hand, loan spreads are more sensitive to the wedge for unrated firms. Consistent with our expectation, all these results suggest that the effect of the divergence between control rights and cash-flow rights on the cost of bank loans is stronger for firms with higher degrees of informational opacity. 


\subsubsection{Borrowing firm credit rating}

The creditworthiness of the borrowing firm might also moderate the relation between the control-ownership wedge and loan spreads. For firms with better creditworthiness, the divergence between control rights and cash-flow rights might be less of a concern to creditors because the likelihood of default is lower. As a result, the creditworthiness of the borrowing firm would weaken the relation between the control-ownership wedge and the firm's borrowing cost. To test this conjecture, we add the interaction between credit quality measures and the control-ownership wedge to the baseline model. We use two different measures of creditworthiness in our tests: the variable $S \& P$ rating (as defined previously with higher values indicating lower credit quality), and a dummy variable Investment grade, which equals one if the credit rating is $\mathrm{BBB}$ or better and zero otherwise. In Table 8, we report the results of re-estimating our baseline model including these creditworthiness proxies and their interactions with the control-ownership wedge.

[Insert Table 8 here]

The results in Table 8 indicate that the loan spreads-wedge sensitivity is significantly higher for borrowers with poor credit ratings (column 1). Conversely, loan spreads are less sensitive to the control-ownership wedge for borrowers with investment-grade ratings (column 2). The effects are both statistically and economically significant. For instance, the coefficients in column 2 imply that a one-standard-deviation increase in the control-ownership wedge increases the average loan spreads of a non-investment-grade firm by 16.5 basis points more than for an investment-grade firm. These results are consistent with our expectation that the effect of the control-ownership wedge on the cost of bank debt is stronger for firms with lower creditworthiness. 
We also split the sample based on the median credit rating and run separate regressions for low- and high-credit rating firms. We find very consistent results that the effect of the ownership-control wedge on bank loan spreads is less pronounced for firms with stronger ratings. For brevity, the results are not reported here in detail but are available from the authors upon request.

\subsection{4. $\quad$ Borrowing firm propping potential}

The pyramid structure for groups of interconnected firms can also facilitate propping (Friedman, Johnson, and Mitton, 2003). The controlling shareholders have incentives to transfer funds from other affiliates in a business group to a specific affiliate in order to preserve their options to expropriate the future profits of the affiliate. In particular, funds are more likely to be transferred out of firms lower down in the pyramid in which the controlling shareholders have low ownership stakes to prop up the firms higher in the pyramid in which the controlling shareholders have high ownership stakes (Bertrand et al., 2002). Therefore, a borrowing firm's potential of being propped up should not only lower its cost of debt financing but also weaken the effect of the control-ownership wedge on loan pricing. ${ }^{25}$

To examine the propping effect, we keep track of the borrowing firm's position in the ownership chain and measure the value of the assets that lie underneath the firm and could potentially be used to prop it up. Specifically, we construct two measures to proxy for the propping potential of the borrowing firm. The first measure equals the total value of the assets of all firms that lie underneath the borrowing firm's position in the pyramid,

${ }^{25}$ Borrowing by groups involves issues more complex than does borrowing by standalone firms. If intra-group lending data were available, we could drill further down and do a more detailed analysis by exploring the direction of intra-group lending flows, cross-guarantees, and cross-default clauses. Another interesting issue is the legal treatment of creditors in pyramids and whether or not a country's bankruptcy code allows creditors to "pierce the corporate veil." Unfortunately, these data are not available to us. 
divided by the borrowing firm's total assets. The second measure is a weighted sum of the values of the assets of all firms that lie underneath the borrowing firm in the pyramid divided by the borrowing firm's total assets. The weight for each firm lower down in the pyramid beneath the borrower is defined as the control rights of the ultimate controlling shareholder on that firm. Thus, the first measure represents an upper bound estimate of the value of assets for potential propping while the second represents a more conservative measure. We then re-estimate our baseline model including these proxies for propping potential and their interactions with the control-ownership wedge. The results are reported in Table 9.

\section{[Insert Table 9 here]}

We use the first measure for borrowing firm propping potential in columns 1 and 2 in Table 9 and the second measure in columns 3 and 4 . The coefficients of the propping potentials measures are indeed significantly negative, indicating that potential propping lowers the cost of borrowing. A one-standard-deviation increase in the propping measures reduces the average loan spread by approximately $8 \%$ to $9 \%$, or 15 to 18 basis points. It is more interesting, however, that our results show that the interaction term between the propping potential measure and the control-ownership wedge is also negative and statistically significant. This suggests that the propping potential of the borrowing firm weakens the link between the control-ownership wedge and loan spreads.

\subsubsection{Loan terms}

Various loan attributes, such as loan type, loan maturity, loan covenants, and collateral, might moderate the relation between the control-ownership wedge and loan spreads. For example, compared with other types of loans, the expropriation risks might be higher for bullet loans since the entire principal would be due at the end of the term as a 
final payment. Similarly, tunneling risks might be higher for loans with longer maturity. Some contractual terms, such as collateral and loan covenants, can be used by lenders as governance mechanisms to mitigate the potential conflicts of interest between large shareholders and creditors and to protect creditors against potential expropriation risks (Cremers et al., 2007). We thus expect a weaker link between loan spreads and the divergence between control rights and cash-flow rights for loans with collateral requirements and restrictive covenants. We examine these potential effects by including variables capturing these loan terms (i.e., loan maturity, the number of loan covenants, whether a facility is a bullet loan, and whether a loan has any collateral) and their interactions with the control-ownership wedge in our baseline model. The empirical results are presented in Table 10.

[Insert Table 10 here]

As expected, the estimates in the first two columns of Table 10 suggest that the positive effect of the control-ownership wedge on loan spreads is greater for bullet loans and loans with longer maturities. On the other hand, the presence of loan covenants or collateral requirements attenuates the effect of excess control rights on loan spreads, as indicated by the negative and statistically significant coefficients of the interaction terms in the last two columns.

\subsubsection{Legal rights and debt enforcement efficiency}

Previous studies (e.g., Esty and Megginson, 2003; Qian and Strahan, 2007) highlight the importance of law and institutions in shaping loan contracts. Stronger creditor rights grant creditors greater ability and bargaining power to force repayment or to take control of firms that default (Qian and Strahan, 2007). Stronger creditor rights may deter tunneling and risk-shifting incentives because creditor rights components, such as 
restrictions on reorganization and no automatic stay, clearly have more negative consequences for the debtor in financial distress.

Shareholder rights, the legal protection of minority shareholders against expropriation by corporate insiders, might also exert a direct impact on the link between the control-ownership wedge and loan spreads. Holding ownership structure constant, better investor protection reduces private benefits of control and therefore reduces tunneling incentives (Djankov et al., 2008b). We use two measures, Anti-director and Anti-self-dealing, of the shareholder rights (La Porta et al., 1998; Djankov et al., 2008b) to gauge the level of protection of investors from insider stealing and self-dealing by controlling shareholders. ${ }^{26}$

In addition to the codified rights, the efficiency of debt enforcement might also matter. Institutions for resolving insolvency cases generally perform poorly, especially in developing countries but also in developed countries to some extent (Djankov et al., 2008a). For example, according to the anecdotal evidence summarized by Friedman, Johnson, and Mitton (2003), creditors in bankruptcy cases in Thailand ultimately receive very little through a process that normally takes up to ten years. More efficient debt enforcement shortens the time and reduces the costs involved in a typical insolvency case and can therefore lower the spreads the lenders charge. We use two measures constructed by Djankov et al. (2008a) to proxy for the efficiency of debt enforcement. Time to payment measures the estimated number of years from the moment of a firm's

26 The anti-director index (La Porta et al., 1998; Djankov et al., 2008b) is formed by adding one when: (1) shareholders are allowed to mail in their proxy votes to the firm; (2) shareholders are not required to deposit their shares before any general shareholders' meeting; (3) cumulative voting or proportional representation of minorities in the board is allowed; (4) minority shareholders have legal mechanisms against perceived oppression by the board of directors; (5) the minimum percentage of share capital that entitles a shareholder to call for a special shareholders' meeting is no more than 10\%; or (6) shareholders have preemptive rights that can be waived only by a shareholders' vote. The index ranges from zero to six with higher values indicating stronger investor protection against insider expropriation. The anti-self-dealing index is computed based on the survey of a hypothetical self-dealing case among attorneys from Lex Mundi law firms in 102 countries (Djankov et al., 2008b). Higher values indicate better protection of investors against self-dealing by controlling shareholders. 
default to the time when the secured creditor gets paid in each country. Cost of debt enforcement proxies for the estimated cost of the insolvency proceeding borne by all parties as a percentage of the value of the insolvent estate in each country.

In Table 11, we report the results for regressions that include the measures for creditor rights, shareholders rights, and debt enforcement efficiency, and their respective interactions with the control-ownership wedge.

[Insert Table 11 here]

As discussed, we expect stronger creditor and shareholder rights and more efficient debt enforcement (shorter time to payment and lower cost) to be associated with lower loan spreads. This is exactly what we find. It is more interesting, however, that the coefficients on the wedge-shareholder rights, wedge-creditor rights, and wedge-debt enforcement efficiency interaction terms are all statistically significant and bear the expected signs. The positive association between the control-ownership wedge and loan spreads is weakened for firms in environments with strong creditor and shareholder rights and efficient debt enforcement.

\subsubsection{Financial crises}

As pointed out in previous studies (e.g., Lemmon and Lins, 2003), financial crises are relatively exogenous shocks, at least with respect to any individual firm, that significantly lower the available return on investment for firms in the affected countries. Holding ownership structure constant, such shocks to returns lower the marginal cost to controlling shareholders of diverting resources away from profitable investment projects and increase the expected level of expropriation (Johnson et al., 2000b). In addition, the legal rights of lenders and minority investors become relatively more important institutions against 
controlling shareholders during times of crisis when growth prospects decline (Johnson et al., 2000b).

We explore the effect of financial crises within a country's banking system on the link between the control-ownership wedge and loan spreads in Table 12. Financial crisis is a dummy variable that takes on the value one if the country is going through a system crisis in the observation year and zero if it is not. A systemic crisis is a situation in which significant segments of the banking sector become insolvent or illiquid, and cannot continue to operate without special assistance from the monetary or supervisory authorities (Demirgüç-Kunt and Detragiache, 2002; Beck et al., 2006). Examples of special assistance include bank holidays, deposit freezes, blanket guarantees to depositors or other bank creditors, and large-scale nationalizations. The banking crisis data are obtained from the Banking Crisis Database, a comprehensive database of banking crisis episodes, compiled by the International Monetary Fund (IMF) economists (Honohan and Laeven, 2005; Laeven and Valencia, 2008). ${ }^{27}$

\section{[Insert Table 12 here]}

The results in Table 12 show that financial crises do exert a significant, positive impact on the link between the control-ownership wedge and loan spreads. The divergence between control rights and cash-flow rights results in much higher costs of bank loans for the firms in countries experiencing financial crises. For example, the coefficients in column 2 indicate that a one-standard-deviation increase in the control-ownership wedge increases loan spreads by $14 \%$ during normal periods and by $20 \%$ during financial crises. In columns 3 to 5, we further interact the interaction between the control-ownership wedge and the crisis indicator with measures for creditor rights and shareholder rights. As before, strong creditor rights and shareholder rights are associated with lower loan spreads in general and lower wedge-loan spread sensitivity. It countries.

27 The banking crisis data set contains panel data with a sample period of 1972 to 2008 covering 93 
is also apparent that the effect of financial crises on the wedge-loan spread sensitivity is weakened in countries with stronger creditor rights and shareholder rights. These results further stress the important role that laws and institutions play in mitigating tunneling and other potential credit risks from controlling shareholders and reducing corporate borrowing costs, especially during financial crises when capital shortages are most severe.

\section{Conclusion}

We study the financial consequences of the divergence between control rights and cash-flow rights in a large sample of companies across 22 East Asian and Western European countries during the period from 1996 to 2008. Specifically, we analyze the effects of control rights-cash-flow rights divergence on firms' cost of borrowing and provide new insights into the link between the separation of ownership and control and corporate value. We find consistent evidence that the control rights-cash-flow rights divergence (control-ownership wedge) results in a much higher cost of debt financing (loan spreads). The loan spreads-wedge sensitivity is much higher for family-controlled firms with family-connected CEOs, firms with greater informational opacity, lower credit ratings, and lower propping potentials, and firms during financial crises. We also find a higher loan spreads-wedge sensitivity for bullet loans, loans with longer maturity, and loans without collateral or covenants. On the other hand, the loan spreads-wedge sensitivity is lower for firms in countries with stronger creditor and shareholder protection and more efficient debt enforcement. Overall, our results shed direct light on the channel through which the divergence between control rights and cash-flow rights affects firm value and highlight the importance of ownership structure in determining the cost of corporate financing. 


\section{References}

Akerlof, G., Romer, P., 1993. Looting: The economic underworld of bankruptcy for profit. Brookings Papers on Economic Activity 2, 1-60.

Anthony, A., Puccia, M., 2005. Flexible gapping of ratings reflects regional variations in structural subordination as well as differing debt-servicing capacities. Standard \& Poor's RatingsDirect (May 25, 2005), 1-11.

Aslan H., Kumar, P., 2009. Controlling shareholders and the agency cost of debt: Evidence from syndicated loans. Unpublished working paper. University of Houston.

Bae, K. H, Goyal, V., 2009. Creditor rights, enforcement, and bank loans. Journal of Finance 64, 823-860.

Barclay, M. J., Smith Jr., C.W., 1995. The maturity structure of corporate debt. Journal of Finance 50, 609-631.

Barclay, M. J., Marx, L. M., Smith Jr., C.W., 2003. The joint determination of leverage and maturity. Journal of Corporate Finance 9, 149-167.

Beck, T., Demirgüç-Kunt, A., Levine, R., 2006. Bank concentration, competition, and crises: First results. Journal of Banking and Finance 30, 1581-1603.

Bertrand, M., Mehta, P., Mullainathan, S., 2002. Ferreting out tunneling: An application to Indian business groups. Quarterly Journal of Economics 117, 121-148.

Bharath, S., Dahiya, S., Saunders, A., Srinivasan A., 2009. Lending relationships and loan contract terms. Review of Financial Studies, forthcoming.

Billett, M., Liu Y., 2008. Shareholder-manager alignment and the cost of debt. Unpublished working paper. University of Iowa.

Bris, A., Welch, I., Zhu, N., 2006. The costs of bankruptcy. Journal of Finance 61, 1253-1303.

Carleton R., Delaney, T., 2009. Using subordination to define intercreditor priority. The RMA Journal (November 2009), 37-39.

Chava, S., Livdan, D., Purnanandam, A., 2009. Do shareholder rights affect the cost of bank loans? Review of Financial Studies 22, 2973-3004. 
Claessens, S., Djankov, S., Lang, L.H.P., 2000. The separation of ownership and control in East Asian corporations. Journal of Financial Economics 58, 81-112.

Claessens, S., Djankov, S., Fan, J., Lang, L.H.P., 2002. Disentangling the incentive and entrenchment effects of large shareholdings. Journal of Finance 57, 2741-2771.

Cremers, M., Nair, V., Wei, C., 2007. Governance mechanisms and bond prices. Review of Financial Studies 20, 1359-1388.

Demirgüç-Kunt, A., Detragiache, E., 2002. Does deposit insurance increase banking system stability? An empirical investigation. Journal of Monetary Economics 49, 1373-1406.

Djankov, S., McLeish, C., Shleifer, A., 2007. Private credit in 129 countries. Journal of Financial Economics 84, 299-329.

Djankov, S., Hart, O., McLiesh, C., Shleifer, A., 2008a. Debt enforcement around the world. Journal of Political Economy 116, 1105-1149.

Djankov, S., La Porta, R., López-de-Silanes, F., Shleifer, A., 2008b. The law and economics of self-dealing. Journal of Financial Economics 88, 430-465.

Esty, B. C., Megginson, W. L., 2003. Creditor rights, enforcement, and debt ownership structure: Evidence from the global syndicated loan market. Journal of Financial and Quantitative Analysis 38, 37-59.

Faccio, M., Lang, L.H.P., 2002. The ultimate ownership of Western European corporations. Journal of Financial Economics 65, 365-395.

Friedman, E., Johnson, S., Mitton, T., 2003. Propping and tunneling. Journal of Comparative Economics 31, 732-750.

Gilson, S. C., Villalonga, B., 2009. Adelphia Communications Corp.'s Bankruptcy. Harvard Business School Case No. 208-071. Harvard Business School Publishing, Boston.

Gompers, P., Ishii, J., Metrick, A., 2010. Extreme governance: An analysis of dual-class firms in the United States. Review of Financial Studies 23, 1051-1088.

Graham, J., Li, S., Qiu, J., 2008. Corporate misreporting and bank loan contracting. 
Journal of Financial Economics 89, 44-61.

Honohan, P., Laeven, L., 2005. Systemic Financial Distress: Containment and Resolution. Cambridge University Press, Cambridge, UK.

Houston, J., Lin, C., Lin, P., Ma, Y., 2010. Creditor rights, information sharing and bank risk taking. Journal of Financial Economics 96, 485-512.

Ivashina, V., 2009. Asymmetric information effects on loan spreads. Journal of Financial Economics 92, 300-319.

Jensen, M., Meckling, W., 1976. Theory of the firm: Managerial behavior, agency costs, and capital structure. Journal of Financial Economics 3, 305-360.

Johnson, S., La Porta, R., López-de-Silanes, F., Shleifer, A., 2000a. Tunneling. American Economic Review 90, 22-27.

Johnson, S., Boone, P., Breach, A., Friedman, E., 2000b. Corporate governance in the Asian financial crisis. Journal of Financial Economic 58, 141-186.

La Porta, R., López-de-Silanes, F., Shleifer, A., Vishny, R., 1998. Law and finance. Journal of Political Economy 106, 1113-1155.

La Porta, R., López-de-Silanes, F., Shleifer, A., 1999. Corporate ownership around the world. Journal of Finance 54, 471-517.

La Porta, R., López-de-Silanes, F., Zamarripa, G., 2003. Related lending. Quarterly Journal of Economics 118, 231-268.

Laeven, L., Levine, R., 2008. Complex ownership structures and corporate valuations. Review of Financial Studies 21, 579-604.

Laeven, L., Levine, R., 2009. Bank governance, regulation and risk taking. Journal of Financial Economics 93, 259-275.

Laeven, L., Valencia, F., 2008. Systemic banking crisis: A new database. IMF Working Paper No. 08/224.

Lemmon, M. L., Lins, K., 2003. Ownership structure, corporate governance, and firm value: Evidence from the East Asian financial crisis. Journal of Finance 58, 1445-1468. 
Lin, C., Lin, P., Song, F., 2010. Property rights protection and corporate R\&D: Evidence from China. Journal of Development Economics 93, 49-62.

Masulis R., Wang C., Xie, F., 2009. Agency cost at dual-class companies. Journal of Finance 64, 1697-1727.

Mitton, T., 2002. A cross-firm analysis of the impact of corporate governance on the East Asian financial crisis. Journal of Financial Economics 64, 214-241.

Nini, G., Smith, D., Sufi, A., 2009. Creditor control rights and firm investment policy. Journal of Financial Economics 92, 400-420.

Purnanandam, A., 2008. Financial distress and corporate risk management: Theory and evidence. Journal of Financial Economics 87, 706-739.

Qian, J., Strahan, P., 2007. How laws and institutions shape financial contracts: The case of bank loans. Journal of Finance 62, 2803-2834.

Shleifer, A., Vishny, R., 1997. A survey of corporate governance. Journal of Finance 52, 737-783.

Villalonga, B., Amit, R., 2006. How do family ownership, control and management affect firm value? Journal of Financial Economics 80, 385-417. 


\section{Table 1}

Definitions of variables

This table provides detailed definitions for all the variables used in the paper.

$\begin{array}{ll}\begin{array}{l}\text { Variable names } \\ \text { Borrower ownership }\end{array} & \text { Variable definitions } \\ \text { Control-ownership wedge } & \begin{array}{l}\text { The difference between the control rights and cash-flow rights of the largest ultimate } \\ \text { owner of the firm } \\ \text { A dummy variable that equals one if the share of control rights of the firm's largest } \\ \text { ultimate owner exceeds the share of cash-flow rights and if this difference is higher than } \\ \text { the median difference in firms where the control-ownership wedge is greater than zero }\end{array} \\ \text { A dummy variable that equals one if the share of control rights of the firm's largest } \\ \text { ultimate owner exceeds the share of cash-flow rights and if this difference is less than or } \\ \text { equal to the median difference in firms where the control-ownership wedge is greater } \\ \text { than zero } \\ \text { The cash-flow rights of the largest ultimate owner of the firm } \\ \text { A dummy variable that equals one if the largest ultimate owner of the firm is a family } \\ \text { and zero otherwise } \\ \text { A dummy variable that equals one if the CEO is a family member of the controlling } \\ \text { family and zero otherwise } \\ \text { A dummy variable that equals one if the largest ultimate owner of the firm is the state } \\ \text { Family CEO dummy }\end{array}$

Borrower characteristics

S\&P ratings

No rating dummy

Leverage

Log assets

Profitability

Q

Tangibility

Cash-flow volatility

Stock index inclusion

Number of analysts

Investment grade

Propping potential

S\&P firm credit ratings are converted to an index from one to seven as follows: $1=$ Aaa, $2=\mathrm{Aa}, 3=\mathrm{A}, 4=\mathrm{Bbb}, 5=\mathrm{Bb}, 6=\mathrm{B}$ or worse, and $7=$ no rating

A dummy variable that equals one if the firm does not have an S\&P credit rating and zero otherwise

(Long-term debt + debt in current liabilities) / total assets

Natural log of total assets measured in millions of US dollars

Net income / total assets

(Market value of equity + Book value of debt) / total assets. Market value of equity equals price per share times total number of shares outstanding. Book value of debt equals total assets minus book value of equity.

Net property, plant, and equipment / total assets

Standard deviation of quarterly cash flows from operations over the four fiscal years prior to the loan initiation year scaled by total debt (long-term debt plus debt in current liabilities)

A dummy variable that equals one if the firm is included in the national major stock index and zero otherwise

Total number of stock analysts following the firm

A dummy variable that equals one if the S\&P rating is BBB or better and zero otherwise

The total value of the assets of all firms that lie underneath the borrowing firm's position in the pyramid, divided by the borrowing firm's total assets (an upper bound measure); or a weighted sum of the values of the assets of all firms that lie underneath the borrowing firm in the pyramid divided by the borrowing firm's total assets, with the weight for each firm lower down in the pyramid beneath the borrower defined as the control rights of the ultimate controlling shareholder on that firm (the more conservative measure)

(continued on the next page) 


\section{Table 1}

Definitions of variables

(Continued)

Variable names $\quad$ Variable definitions

\section{Loan characteristics}

Log loan spreads

Log loan size

Log loan maturity

Performance pricing dummy

Term loan dummy

Loan purpose dummies

Bullet loan dummy

Number of covenants

Collateral dummy

Macroeconomic factors

Creditor rights

Sovereign risk rating

Private credit to GDP

Log GDP per capita

Anti-self-dealing

Anti-director

Time to payment

Cost of debt enforcement

Financial crisis dummy
Natural log of the loan spread. Loan spread is the all-in-spread drawn, defined as the amount the borrower pays in basis points over LIBOR or LIBOR equivalent for the drawn portion of the loan facility.

Natural log of the loan facility amount, measured in millions of US dollars

Natural log of the loan maturity measured in days

A dummy variable that equals one if the loan uses performance pricing and zero otherwise

A dummy variable that equals one if the loan facility is a term loan and zero otherwise

Dummy variables for loan purposes, including refinancing, acquisition, capital expenditure, backup line, working capital, corporate purposes, and others

A dummy variable that equals one if the loan facility is a bullet loan and zero otherwise

Total number of covenants for the loan

A dummy variable that equals one if the loan is secured by collateral and zero otherwise

An index aggregating creditor rights (La Porta et al., 1998; Djankov et al., 2007). This index consists of four components: (1) whether there are restrictions imposed, such as creditors' consent, when a debtor files for reorganization (Restrictions on reorganization); (2) whether secured creditors have the ability to seize collateral after the petition for reorganization is approved (No automatic stay); (3) whether secured creditors are ranked first in the distribution of proceeds from liquidation as opposed to other creditors such as employees (Secured creditor paid first); and (4) whether an administrator, rather than the incumbent management, is in control of and responsible for running the business during the reorganization (No management stay). A value of one is added to the index when a country's laws and regulations provide each of these powers to secured creditors to arrive at the aggregate creditor rights index. The aggregate creditor rights index ranges from zero to four, with higher values indicating stronger creditor rights.

Moody's ratings on the long-term sovereign (government) bonds for the borrower's country (denominated in US dollars) are converted into an index from one to six as follows: $1=$ Aaa, 2 $=\mathrm{Aa}, 3=\mathrm{A}, 4=\mathrm{Bbb}, 5=\mathrm{Bb}$, and $6=\mathrm{B}$ or worse

Private credit by commercial banks and other financial institutions / GDP

Natural log of the real GDP per capita in US dollars (USD)

An index computed based on the survey of a hypothetical self-dealing case among attorneys from Lex Mundi law firms in 102 countries (Djankov et al., 2008b). Higher values indicate better protection of investors against self-dealing by controlling shareholders.

An index compiled by La Porta et al. (1998) and Djankov et al. (2008b). This index is formed by adding one when: (1) shareholders are allowed to mail in their proxy votes to the firm; (2) shareholders are not required to deposit shares before any general shareholders' meeting; (3) cumulative voting or proportional representation of minorities in the board is allowed; (4) minority shareholders have legal mechanisms against perceived oppression by the board; (5) the minimum percentage of share capital that entitles a shareholder to call for a special shareholders' meeting is no more than $10 \%$; or (6) shareholders have preemptive rights that can be waived only by a shareholders' vote. The index ranges from zero to six with higher values indicating stronger investor protection against insider expropriation.

The estimated number of years from the moment of a firm's default to the time when the secured creditor gets paid in each country (Djankov et al., 2008a)

The estimated cost of the insolvency proceeding borne by all parties divided by the value of the insolvency estate in each country (Djankov et al., 2008a)

A dummy variable that equals one if the country is going through a financial crisis in the observation year and zero if it is not. Crisis data are obtained from the Banking Crisis Database, a comprehensive database of banking crisis episodes, compiled by IMF economists (Honohan and Laeven, 2005; Laeven and Valencia, 2008). 
Table 2

Summary statistics

This table presents the mean, standard deviation (STD), and number of observations $(N)$ for all the variables used in the paper. The sample consists of 13,331 bank loans made to 3,468 firms in 22 Western European and East Asian countries during the period from 1996 to 2008. Definitions of all the variables are reported in Table 1.

\begin{tabular}{|c|c|c|c|}
\hline Variable names & Mean & STD & $N$ \\
\hline \multicolumn{4}{|l|}{ Borrower ownership } \\
\hline Control-ownership wedge & 0.061 & 0.126 & 13,331 \\
\hline High-wedge dummy & 0.119 & 0.324 & 13,331 \\
\hline Low-wedge dummy & 0.122 & 0.327 & 13,331 \\
\hline Cash-flow rights & 0.259 & 0.251 & 13,331 \\
\hline Family dummy & 0.452 & 0.497 & 13,331 \\
\hline Family CEO dummy & 0.077 & 0.266 & 13,331 \\
\hline State dummy & 0.069 & 0.252 & 13,331 \\
\hline \multicolumn{4}{|l|}{ Borrower characteristics } \\
\hline S\&P ratings & 1.169 & 1.742 & 13,331 \\
\hline No rating dummy & 0.380 & 0.485 & 13,331 \\
\hline Leverage & 0.334 & 0.299 & 13,331 \\
\hline Total assets (\$MM) & 4,849 & 21,020 & 13,331 \\
\hline Profitability & 0.091 & 0.079 & 13,331 \\
\hline Q & 1.337 & 0.511 & 13,331 \\
\hline Tangibility & 0.530 & 0.272 & 13,331 \\
\hline Cash-flow volatility & 2.073 & 2.287 & 13,331 \\
\hline Stock index inclusion & 0.763 & 0.425 & 13,331 \\
\hline Number of analysts & 11.345 & 11.862 & 13,331 \\
\hline Propping potential (upper bound) & 0.462 & 0.735 & 13,331 \\
\hline Propping potential (conservative) & 0.094 & 0.152 & 13,331 \\
\hline Investment grade & 0.412 & 0.492 & 13,331 \\
\hline \multicolumn{4}{|l|}{ Loan characteristics } \\
\hline Loan spreads (basis points) & 195.352 & 174.096 & 13,331 \\
\hline Loan size (\$MM) & 369 & 1,120 & 13,197 \\
\hline Loan maturity (days) & 1,608 & 1,025 & 13,103 \\
\hline Performance pricing dummy & 0.064 & 0.245 & 13,331 \\
\hline Term loan dummy & 0.407 & 0.491 & 13,331 \\
\hline Bullet loan dummy & 0.229 & 0.420 & 13,331 \\
\hline Number of covenants & 6.723 & 3.715 & 13,331 \\
\hline Collateral dummy & 0.326 & 0.469 & 13,331 \\
\hline \multicolumn{4}{|l|}{ Macroeconomic factors } \\
\hline Creditor rights & 2.494 & 1.279 & 13,331 \\
\hline Sovereign risk rating & 1.691 & 0.897 & 13,331 \\
\hline Private credit to GDP & 1.156 & 0.672 & 13,331 \\
\hline GDP per capita & 21,046 & 9,185 & 13,331 \\
\hline Anti-self-dealing & 0.627 & 0.261 & 13,331 \\
\hline Anti-director & 3.845 & 0.853 & 13,331 \\
\hline Time to payment & 1.416 & 1.001 & 13,331 \\
\hline Cost of debt enforcement & 0.085 & 0.056 & 13,331 \\
\hline Financial crisis dummy & 0.246 & 0.431 & 13,331 \\
\hline
\end{tabular}




\section{Table 3}

The effect of the control-ownership wedge on loan pricing

This table presents the regression results on the effect of the control-ownership wedge on loan pricing. The sample consists of 13,331 bank loans made to 3,468 firms in 22 Western European and East Asian countries during the period from 1996 to 2008. The dependent variable is the log loan spread for a single bank loan. The control-ownership wedge is defined as the difference between the control rights and cash-flow rights of the largest ultimate owner of the firm. Definitions of all the other variables are reported in Table 1. $P$-Values based on robust standard errors clustered by firm are reported in brackets. Significance at the $10 \%, 5 \%$, and $1 \%$ level is indicated by *, **, and ***, respectively.

\begin{tabular}{|c|c|c|c|c|c|c|c|c|}
\hline & $(1)$ & $(2)$ & (3) & $(4)$ & (5) & (6) & $(7)$ & (8) \\
\hline \multirow[t]{2}{*}{ High-wedge dummy } & 0.252 & 0.285 & 0.248 & 0.184 & & & & \\
\hline & {$[0.000]^{* * *}$} & {$[0.000]^{* * *}$} & {$[0.001]^{* * *}$} & {$[0.003]^{* * *}$} & & & & \\
\hline \multirow[t]{2}{*}{ Low-wedge dummy } & 0.138 & 0.132 & 0.120 & 0.087 & & & & \\
\hline & {$[0.002]^{* * *}$} & {$[0.015]^{* *}$} & {$[0.016]^{* *}$} & {$[0.027]^{* *}$} & & & & \\
\hline \multirow[t]{2}{*}{ Control-ownership wedge } & & & & & 1.541 & 1.533 & 1.433 & 1.127 \\
\hline & & & & & {$[0.000]^{* * *}$} & {$[0.000]^{* * *}$} & {$[0.007]^{* * *}$} & {$[0.008]^{* * *}$} \\
\hline \multirow[t]{2}{*}{ Cash-flow rights } & -0.427 & -0.412 & -0.411 & -0.378 & -0.354 & -0.391 & -0.402 & -0.369 \\
\hline & {$[0.019]^{* *}$} & {$[0.006]^{* * *}$} & {$[0.027]^{* *}$} & {$[0.029]^{* *}$} & {$[0.026]^{* *}$} & {$[0.042]^{* *}$} & {$[0.030]^{* *}$} & {$[0.032]^{* *}$} \\
\hline \multirow[t]{2}{*}{ Leverage } & 0.654 & 0.604 & 0.412 & 0.367 & 0.504 & 0.476 & 0.415 & 0.379 \\
\hline & [0.168] & [0.115] & {$[0.059]^{*}$} & {$[0.068]^{*}$} & {$[0.028]^{* *}$} & {$[0.053]^{*}$} & {$[0.057]^{*}$} & {$[0.065]^{*}$} \\
\hline \multirow[t]{2}{*}{ Tangibility } & -0.201 & -0.183 & -0.130 & -0.115 & -0.13 & -0.163 & -0.125 & -0.110 \\
\hline & {$[0.060]^{*}$} & [0.191] & {$[0.010]^{* *}$} & {$[0.012]^{* *}$} & [0.104] & [0.137] & {$[0.010]^{* * *}$} & {$[0.011]^{* *}$} \\
\hline \multirow[t]{2}{*}{ Log assets } & -0.436 & -0.406 & -0.339 & -0.321 & -0.371 & -0.356 & -0.332 & -0.316 \\
\hline & {$[0.026]^{* *}$} & {$[0.046]^{* *}$} & {$[0.033]^{* *}$} & {$[0.037]^{* *}$} & {$[0.053]^{*}$} & {$[0.029]^{* *}$} & {$[0.037]^{* *}$} & {$[0.040]^{* *}$} \\
\hline \multirow[t]{2}{*}{ Profitability } & -0.948 & -0.84 & -0.881 & -0.786 & -0.63 & -0.646 & -0.862 & -0.771 \\
\hline & {$[0.030]^{* *}$} & [0.182] & {$[0.065]^{*}$} & {$[0.090]^{*}$} & {$[0.027]^{* *}$} & {$[0.196]$} & {$[0.072]^{*}$} & {$[0.094]^{*}$} \\
\hline \multirow[t]{2}{*}{ Cash-flow volatility } & 0.020 & 0.019 & 0.015 & 0.014 & 0.022 & 0.025 & 0.017 & 0.016 \\
\hline & [0.189] & {$[0.014]^{* *}$} & {$[0.206]$} & {$[0.238]$} & {$[0.052]^{*}$} & {$[0.060]^{*}$} & {$[0.106]$} & [0.129] \\
\hline \multirow[t]{2}{*}{ S\&P ratings } & & & & 0.126 & & & & 0.137 \\
\hline & & & & {$[0.061]^{*}$} & & & & [0.069]* \\
\hline \multirow[t]{2}{*}{ No rating dummy } & & & & 0.142 & & & & 0.131 \\
\hline & & & & [0.102] & & & & {$[0.094]^{*}$} \\
\hline \multirow[t]{2}{*}{$Q$} & & & & -0.104 & & & & -0.099 \\
\hline & & & & {$[0.058]^{*}$} & & & & {$[0.061]^{*}$} \\
\hline \multirow[t]{2}{*}{ Performance pricing dummy } & & -0.031 & -0.018 & -0.016 & & -0.023 & -0.020 & -0.018 \\
\hline & & {$[0.029]^{* *}$} & {$[0.058]^{*}$} & {$[0.062]^{*}$} & & {$[0.017]^{* *}$} & {$[0.051]^{*}$} & {$[0.054]^{*}$} \\
\hline \multirow[t]{2}{*}{ Term loan dummy } & & 0.050 & 0.041 & 0.038 & & 0.055 & 0.04 & 0.038 \\
\hline & & {$[0.017]^{* *}$} & {$[0.034]^{* *}$} & {$[0.037]^{* *}$} & & {$[0.041]^{* *}$} & {$[0.033]^{* *}$} & {$[0.035]^{* *}$} \\
\hline \multirow[t]{2}{*}{ Log loan size } & & -0.034 & -0.029 & -0.027 & & -0.036 & -0.031 & -0.029 \\
\hline & & {$[0.025]^{* *}$} & {$[0.059]^{*}$} & {$[0.063]^{*}$} & & {$[0.030]^{* *}$} & {$[0.057]^{*}$} & {$[0.061]^{*}$} \\
\hline \multirow[t]{2}{*}{ Log loan maturity } & & 0.098 & 0.079 & 0.074 & & 0.086 & 0.080 & 0.074 \\
\hline & & {$[0.034]^{* *}$} & {$[0.057]^{*}$} & {$[0.061]^{*}$} & & {$[0.011]^{* *}$} & {$[0.054]^{*}$} & {$[0.058]^{*}$} \\
\hline
\end{tabular}




\section{Table 3}

The effect of the control-ownership wedge on loan pricing (Continued)

\begin{tabular}{|c|c|c|c|c|c|c|c|c|}
\hline & (1) & $(2)$ & (3) & (4) & (5) & (6) & (7) & (8) \\
\hline \multirow[t]{2}{*}{ Sovereign risk rating } & & & 0.171 & 0.180 & & & 0.165 & 0.173 \\
\hline & & & {$[0.126]$} & [0.117] & & & [0.131] & [0.123] \\
\hline \multirow[t]{2}{*}{ Creditor rights } & & & -0.149 & -0.158 & & & -0.144 & -0.153 \\
\hline & & & {$[0.030]^{* *}$} & {$[0.029]^{* *}$} & & & {$[0.027]^{* *}$} & {$[0.026]^{* *}$} \\
\hline \multirow[t]{2}{*}{ Private credit to GDP } & & & 0.358 & 0.377 & & & 0.371 & 0.390 \\
\hline & & & {$[0.029]^{* *}$} & {$[0.028]^{* *}$} & & & {$[0.022]^{* *}$} & {$[0.021]^{* *}$} \\
\hline \multirow[t]{2}{*}{ Log GDP per capita } & & & -0.036 & -0.034 & & & -0.037 & -0.035 \\
\hline & & & {$[0.072]^{*}$} & {$[0.076]^{*}$} & & & {$[0.068]^{*}$} & {$[0.072]^{*}$} \\
\hline Loan purpose dummies & No & Yes & Yes & Yes & No & Yes & Yes & Yes \\
\hline Industry effects & No & Yes & Yes & Yes & No & Yes & Yes & Yes \\
\hline Time effects & No & Yes & Yes & Yes & No & Yes & Yes & Yes \\
\hline Number of observations & 13,331 & 12,973 & 12,973 & 12,973 & 13,331 & 12,973 & 12,973 & 12,973 \\
\hline Number of Firms & 3,468 & 3,402 & 3,402 & 3,402 & 3,468 & 3,402 & 3,402 & 3,402 \\
\hline Adjusted $R^{2}$ & 0.210 & 0.224 & 0.221 & 0.237 & 0.216 & 0.225 & 0.218 & 0.247 \\
\hline
\end{tabular}




\section{Table 4}

\section{Instrumental variables estimation}

This table presents the results of instrumental variables estimations of the effect of the control-ownership wedge on loan pricing. The sample consists of 13,331 bank loans made to 3,468 firms in 22 Western European and East Asian countries during the period from 1996 to 2008. The dependent variable is the log loan spread. The control-ownership wedge is defined as the difference between the control rights and cash-flow rights of the largest ultimate owner of the firm. The instruments for the control-ownership wedge and cash-flow rights are the initial industry average difference between control rights and cash-flow rights and the initial industry average cash-flow rights, respectively. Definitions of all the other variables are reported in Table 1. $P$-Values based on robust standard errors clustered by firm are reported in brackets. Significance at the $10 \%, 5 \%$, and $1 \%$ level is indicated by $*$, **, and ${ }^{* * *}$, respectively.

\begin{tabular}{|c|c|c|c|}
\hline & $(1)$ & $(2)$ & (3) \\
\hline \multirow[t]{2}{*}{ Control-ownership wedge } & 2.424 & 2.291 & 2.018 \\
\hline & {$[0.000]^{* * *}$} & {$[0.007]^{* * *}$} & {$[0.006]^{* * *}$} \\
\hline \multirow[t]{2}{*}{ Cash-flow rights } & -0.747 & -0.848 & -0.771 \\
\hline & {$[0.021]^{* *}$} & {$[0.002]^{* * *}$} & {$[0.014]^{* *}$} \\
\hline \multirow[t]{2}{*}{ S\&P ratings } & 0.194 & 0.179 & 0.155 \\
\hline & {$[0.014]^{* *}$} & {$[0.036]^{* *}$} & {$[0.070]^{*}$} \\
\hline \multirow[t]{2}{*}{ No rating dummy } & 0.146 & 0.130 & 0.128 \\
\hline & {$[0.046]^{* *}$} & [0.133] & {$[0.074]^{*}$} \\
\hline \multirow[t]{2}{*}{ Leverage } & 0.426 & 0.340 & 0.211 \\
\hline & {$[0.034]^{* *}$} & {$[0.089]^{*}$} & {$[0.067]^{*}$} \\
\hline \multirow[t]{2}{*}{ Tangibility } & -0.118 & -0.106 & -0.096 \\
\hline & {$[0.031]^{* *}$} & [0.097]* & {$[0.071]^{*}$} \\
\hline \multirow[t]{2}{*}{ Log assets } & -0.329 & -0.312 & -0.265 \\
\hline & {$[0.085]^{*}$} & {$[0.028]^{* *}$} & {$[0.031]^{* *}$} \\
\hline \multirow[t]{2}{*}{$Q$} & -0.095 & -0.121 & -0.106 \\
\hline & {$[0.029]^{* *}$} & {$[0.073]^{*}$} & {$[0.053]^{*}$} \\
\hline \multirow[t]{2}{*}{ Profitability } & -0.570 & -0.511 & -0.502 \\
\hline & {$[0.032]^{* *}$} & {$[0.182]$} & [0.107] \\
\hline \multirow[t]{2}{*}{ Cash-flow volatility } & 0.022 & 0.020 & 0.019 \\
\hline & {$[0.046]^{* *}$} & {$[0.061]^{*}$} & {$[0.127]$} \\
\hline \multirow[t]{2}{*}{ Performance pricing dummy } & & -0.025 & -0.021 \\
\hline & & {$[0.017]^{* *}$} & {$[0.050]^{*}$} \\
\hline \multirow[t]{2}{*}{ Term loan dummy } & & 0.051 & 0.034 \\
\hline & & {$[0.040]^{* *}$} & {$[0.038]^{* *}$} \\
\hline \multirow[t]{2}{*}{ Log loan size } & & -0.035 & -0.030 \\
\hline & & {$[0.037]^{* *}$} & {$[0.061]^{*}$} \\
\hline \multirow[t]{2}{*}{ Log loan maturity } & & 0.079 & 0.069 \\
\hline & & {$[0.024]^{* *}$} & {$[0.038]^{* *}$} \\
\hline
\end{tabular}

(continued on the next page) 


\section{Table 4}

Instrumental variables estimation

(Continued)

\begin{tabular}{llll}
\hline & $(1)$ & $(2)$ & $(3)$ \\
\hline Sovereign risk rating & & 0.193 \\
Creditor rights & & {$[0.022]^{* *}$} \\
& & -0.171 \\
Private credit to GDP & & {$[0.033]^{* *}$} \\
& & 0.304 \\
Log GDP per capita & & {$[0.041]^{* *}$} \\
& & -0.035 \\
Loan purpose dummies & & {$[0.082]^{*}$} \\
Industry effects & No & Yes & Yes \\
Time effects & No & Yes & Yes \\
Number of observations & No & Yes & Yes \\
Number of firms & 13,331 & 12,973 & 12,973 \\
Adjusted $R^{2}$ & 3,468 & 3,402 & 3,402 \\
\hline
\end{tabular}


Table 5

Change regressions

This table presents the OLS regression results on the effect of changes in the borrower control-ownership wedge on changes in loan pricing. The sample consists of bank loans made to firms in 22 Western European and East Asian countries during the period from 1996 to 2008. The dependent variable is the change in the log loan spread. The control-ownership wedge is defined as the difference between the control rights and cash-flow rights of the largest ultimate owner of the firm. Definitions of all the other variables are reported in Table 1. $P$-Values based on robust standard errors clustered by firm are reported in brackets. Significance at the $10 \%, 5 \%$, and $1 \%$ level is indicated by *, **, and ${ }^{* * *}$, respectively.

\begin{tabular}{|c|c|c|c|}
\hline & $(1)$ & (2) & (3) \\
\hline \multirow[t]{2}{*}{$\Delta$ Control-ownership wedge } & 1.375 & 1.349 & 1.266 \\
\hline & {$[0.000]^{* * *}$} & {$[0.000]^{* * *}$} & {$[0.003]^{* * *}$} \\
\hline \multirow[t]{2}{*}{$\Delta$ Cash-flow rights } & -0.276 & -0.262 & -0.268 \\
\hline & {$[0.029]^{* *}$} & {$[0.032]^{* *}$} & {$[0.037]^{* *}$} \\
\hline \multirow[t]{2}{*}{$\Delta \mathrm{S} \& \mathrm{P}$ ratings } & & 0.166 & 0.244 \\
\hline & & {$[0.118]$} & {$[0.067]^{*}$} \\
\hline \multirow[t]{2}{*}{$\Delta$ Leverage } & & 0.486 & 0.475 \\
\hline & & {$[0.072]^{*}$} & {$[0.076]^{*}$} \\
\hline \multirow[t]{2}{*}{$\Delta$ Tangibility } & & -0.152 & -0.138 \\
\hline & & {$[0.023]^{* *}$} & {$[0.037]^{* *}$} \\
\hline \multirow[t]{2}{*}{$\Delta$ Log assets } & & -0.627 & -0.585 \\
\hline & & {$[0.038]^{* *}$} & {$[0.029]^{* *}$} \\
\hline \multirow[t]{2}{*}{$\Delta Q$} & & -0.208 & -0.395 \\
\hline & & {$[0.101]$} & {$[0.068]^{*}$} \\
\hline \multirow[t]{2}{*}{$\Delta$ Profitability } & & -0.732 & -0.643 \\
\hline & & {$[0.155]$} & {$[0.067]^{*}$} \\
\hline \multirow[t]{2}{*}{$\Delta$ Cash-flow volatility } & & 0.024 & 0.026 \\
\hline & & {$[0.231]$} & {$[0.207]$} \\
\hline \multirow[t]{2}{*}{$\Delta$ Log loan size } & & & -0.046 \\
\hline & & & {$[0.065]^{*}$} \\
\hline \multirow[t]{2}{*}{$\Delta$ Log loan maturity } & & & 0.047 \\
\hline & & & {$[0.084]^{*}$} \\
\hline \multirow[t]{2}{*}{$\Delta$ Sovereign risk rating } & & & 0.128 \\
\hline & & & {$[0.237]$} \\
\hline \multirow[t]{2}{*}{$\Delta$ Creditor rights } & & & -0.264 \\
\hline & & & {$[0.038]^{* *}$} \\
\hline \multirow[t]{2}{*}{$\Delta$ Private credit to GDP } & & & 0.478 \\
\hline & & & {$[0.026]^{* *}$} \\
\hline \multirow[t]{2}{*}{$\Delta$ Log GDP per capita } & & & -0.023 \\
\hline & & & {$[0.081]^{*}$} \\
\hline \multirow[t]{2}{*}{ Constant } & -0.051 & -0.049 & -0.028 \\
\hline & {$[0.067]^{*}$} & {$[0.152]$} & {$[0.324]$} \\
\hline Number of observations & 2,038 & 2,038 & 2,038 \\
\hline Number of firms & 1,037 & 1,037 & 1,037 \\
\hline Adjusted $R^{2}$ & 0.104 & 0.126 & 0.142 \\
\hline
\end{tabular}




\section{Table 6}

Ownership identity and the effect of the control-ownership wedge on loan pricing

This table presents the regression results on the effect of ownership identity on the relation between the control-ownership wedge and loan pricing. The sample consists of bank loans made to firms in 22 Western European and East Asian countries during the period from 1996 to 2008. The dependent variable is the log loan spread. The control-ownership wedge is defined as the difference between the control rights and cash-flow rights of the largest ultimate owner of the firm. Family dummy equals one if the largest ultimate owner of the firm is a family and zero otherwise. Family CEO dummy equals one if the CEO is a family member of the controlling family and zero otherwise. State dummy equals one if the largest ultimate owner of the firm is the state and zero otherwise. Definitions of all the other variables are reported in Table 1. $P$-Values based on robust standard errors clustered by firm are reported in brackets. Significance at the $10 \%, 5 \%$, and $1 \%$ level is indicated by $*, * *$, and ${ }^{* * *}$, respectively.

\begin{tabular}{|c|c|c|c|c|}
\hline & (1) & (2) & (3) & (4) \\
\hline \multirow[t]{2}{*}{ Control-ownership wedge } & 1.309 & 1.300 & 1.287 & 1.113 \\
\hline & {$[0.012]^{* *}$} & {$[0.004]^{* * *}$} & {$[0.008]^{* * *}$} & {$[0.029]^{* *}$} \\
\hline \multirow[t]{2}{*}{ Family dummy } & 0.225 & 0.222 & 0.223 & 0.221 \\
\hline & {$[0.014]^{* *}$} & {$[0.026]^{* *}$} & {$[0.012]^{* *}$} & {$[0.018]^{* *}$} \\
\hline \multirow[t]{2}{*}{ Family x Wedge } & & 0.544 & 0.510 & 0.504 \\
\hline & & {$[0.003]^{* * *}$} & {$[0.018]^{* *}$} & {$[0.023]^{* *}$} \\
\hline \multirow[t]{2}{*}{ Family CEO dummy } & & & 0.174 & 0.172 \\
\hline & & & {$[0.016]^{* *}$} & {$[0.018]^{* *}$} \\
\hline \multirow[t]{2}{*}{ Family CEO x Wedge } & & & 0.380 & 0.385 \\
\hline & & & {$[0.023]^{* *}$} & {$[0.029]^{* *}$} \\
\hline \multirow[t]{2}{*}{ State dummy } & & & & -0.055 \\
\hline & & & & {$[0.081]^{*}$} \\
\hline \multirow[t]{2}{*}{ State $\mathrm{x}$ Wedge } & & & & -0.249 \\
\hline & & & & {$[0.036]^{* *}$} \\
\hline \multirow[t]{2}{*}{ Cash-flow rights } & -0.435 & -0.478 & -0.386 & -0.421 \\
\hline & {$[0.023]^{* *}$} & {$[0.014]^{* *}$} & {$[0.028]^{* *}$} & {$[0.032]^{* *}$} \\
\hline \multirow[t]{2}{*}{ S\&P ratings } & -0.138 & -0.121 & -0.108 & 0.093 \\
\hline & {$[0.026]^{* *}$} & {$[0.051]^{*}$} & {$[0.020]^{* *}$} & {$[0.059]^{*}$} \\
\hline \multirow[t]{2}{*}{ No rating dummy } & -0.184 & -0.174 & -0.131 & 0.145 \\
\hline & {$[0.026]^{* *}$} & {$[0.053]^{*}$} & {$[0.032]^{* *}$} & {$[0.092]^{*}$} \\
\hline \multirow[t]{2}{*}{ Leverage } & 0.316 & 0.337 & 0.316 & 0.360 \\
\hline & {$[0.032]^{* *}$} & {$[0.056]^{*}$} & {$[0.031]^{* *}$} & {$[0.029]^{* *}$} \\
\hline \multirow[t]{2}{*}{ Tangibility } & -0.135 & -0.135 & -0.138 & -0.186 \\
\hline & {$[0.084]^{*}$} & {$[0.043]^{* *}$} & {$[0.079]^{*}$} & {$[0.095]^{*}$} \\
\hline \multirow[t]{2}{*}{ Log assets } & -0.147 & -0.144 & -0.146 & -0.311 \\
\hline & {$[0.032]^{* *}$} & {$[0.041]^{* *}$} & {$[0.061]^{*}$} & {$[0.051]^{*}$} \\
\hline \multirow[t]{2}{*}{$Q$} & -0.067 & -0.061 & -0.067 & -0.062 \\
\hline & {$[0.032] * *$} & {$[0.075]^{*}$} & {$[0.067]^{*}$} & {$[0.088]^{*}$} \\
\hline \multirow[t]{2}{*}{ Profitability } & -0.772 & -0.773 & -0.764 & -0.794 \\
\hline & {$[0.092]^{*}$} & {$[0.011]^{* *}$} & {$[0.072]^{*}$} & {$[0.020]^{* *}$} \\
\hline \multirow[t]{2}{*}{ Cash-flow volatility } & 0.017 & 0.014 & 0.015 & 0.014 \\
\hline & {$[0.077]^{*}$} & {$[0.018]^{* *}$} & {$[0.016]^{* *}$} & {$[0.038]^{* *}$} \\
\hline
\end{tabular}

(continued on the next page) 


\section{Table 6}

Ownership identity and the effect of the control-ownership wedge on loan pricing (Continued)

\begin{tabular}{lllll}
\hline & $(1)$ & $(2)$ & $(3)$ & \multicolumn{1}{c}{$(4)$} \\
\hline Performance pricing dummy & -0.012 & -0.015 & -0.018 & -0.015 \\
Term loan dummy & {$[0.046]^{* *}$} & {$[0.091]^{*}$} & {$[0.024]^{* *}$} & {$[0.184]$} \\
& 0.031 & 0.032 & 0.032 & 0.038 \\
Log loan size & {$[0.035]^{* *}$} & {$[0.063]^{*}$} & {$[0.016]^{* *}$} & {$[0.035]^{* *}$} \\
& -0.026 & -0.023 & -0.031 & -0.029 \\
Log loan maturity & {$[0.033]^{* *}$} & {$[0.162]$} & {$[0.071]^{*}$} & {$[0.048]^{* *}$} \\
& 0.094 & 0.069 & 0.053 & 0.074 \\
Sovereign risk rating & {$[0.078]^{*}$} & {$[0.034]^{* *}$} & {$[0.069]^{*}$} & {$[0.039]^{* *}$} \\
& -0.156 & -0.154 & -0.173 & 0.197 \\
Creditor rights & {$[0.127]$} & {$[0.108]$} & {$[0.034]^{* *}$} & {$[0.066]^{*}$} \\
Private credit to GDP & -0.135 & -0.117 & -0.143 & -0.131 \\
& {$[0.027]^{* *}$} & {$[0.028]^{* *}$} & {$[0.065]^{*}$} & {$[0.055]^{*}$} \\
Log GDP per capita & 0.425 & 0.596 & 0.409 & 0.397 \\
Time effects & {$[0.043]^{* *}$} & {$[0.057]^{*}$} & {$[0.144]$} & {$[0.029]^{* *}$} \\
Number of observations & -0.022 & -0.034 & -0.040 & -0.036 \\
Number of firms & {$[0.063]^{*}$} & {$[0.016]^{* *}$} & {$[0.182]$} & {$[0.092]^{*}$} \\
Adjusted $R^{2}$ & Yes & Yes & Yes & Yes \\
Loan purpose dummies & Yes & Yes & Yes & Yes \\
Industry effects & Yes & Yes & Yes & Yes \\
Tim & 12,593 & 12,593 & 12,593 & 12,593 \\
& 3,276 & 3,276 & 3,276 & 3,276 \\
& 0.242 & 0.245 & 0.241 & 0.244 \\
\hline
\end{tabular}


Table 7

Borrowing firm informational opacity and the effect of the control-ownership wedge on loan pricing

This table presents the regression results on the effect of borrowing firm informational opacity on the relation between the control-ownership wedge and loan pricing. The sample consists of bank loans made to firms in 22 Western European and East Asian countries during the period from 1996 to 2008. The dependent variable is the log loan spread. The control-ownership wedge is defined as the difference between the control rights and cash-flow rights of the largest ultimate owner of the firm. No rating dummy equals one if the firm does not have an S\&P credit rating and zero otherwise. Stock index inclusion is a dummy variable that equals one if the firm is included in a national major stock index and zero otherwise. Number of analysts is the total number of stock analysts following the firm. Definitions of all the other variables are reported in Table 1. $P$-Values based on robust standard errors clustered by firm are reported in brackets. Significance at the $10 \%, 5 \%$, and $1 \%$ level is indicated by *, **, and ***, respectively.

\begin{tabular}{|c|c|c|c|c|}
\hline & (1) & (2) & (3) & (4) \\
\hline \multirow[t]{2}{*}{ Control-ownership wedge } & 1.273 & 1.299 & 1.147 & 1.146 \\
\hline & {$[0.006]^{* * *}$} & {$[0.012]^{* *}$} & {$[0.014]^{* *}$} & {$[0.003]^{* * *}$} \\
\hline \multirow[t]{2}{*}{ Log assets $x$ Wedge } & -0.017 & & & \\
\hline & {$[0.019]^{* *}$} & & & \\
\hline \multirow[t]{2}{*}{ No rating dummy x Wedge } & & 0.424 & & \\
\hline & & {$[0.002]^{* * *}$} & & \\
\hline \multirow[t]{2}{*}{ Stock index inclusion x Wedge } & & & -0.239 & \\
\hline & & & {$[0.003]^{* * *}$} & \\
\hline \multirow[t]{2}{*}{ Stock index inclusion } & & & -0.055 & \\
\hline & & & {$[0.025]^{* *}$} & \\
\hline \multirow[t]{2}{*}{ Number of analysts x Wedge } & & & & -0.262 \\
\hline & & & & {$[0.006]^{* * *}$} \\
\hline \multirow[t]{2}{*}{ Number of analysts } & & & & -0.580 \\
\hline & & & & {$[0.029]^{* *}$} \\
\hline \multirow[t]{2}{*}{ No rating dummy } & 0.151 & 0.125 & 0.160 & 0.245 \\
\hline & {$[0.037]^{* *}$} & {$[0.008]^{* * *}$} & {$[0.095]^{*}$} & {$[0.076]^{*}$} \\
\hline \multirow[t]{2}{*}{ Log assets } & -0.224 & -0.306 & -0.333 & -0.287 \\
\hline & {$[0.058]^{*}$} & {$[0.038]^{* *}$} & {$[0.033]^{* *}$} & {$[0.063]^{*}$} \\
\hline \multirow[t]{2}{*}{ Cash-flow rights } & -0.350 & -0.348 & -0.346 & -0.415 \\
\hline & {$[0.032]^{* *}$} & {$[0.017]^{* *}$} & {$[0.048]^{* *}$} & {$[0.025]^{* *}$} \\
\hline
\end{tabular}

(continued on the next page) 
Table 7

Borrowing firm informational opacity and the effect of the control-ownership wedge on loan pricing

(Continued)

\begin{tabular}{|c|c|c|c|c|}
\hline & (1) & (2) & (3) & (4) \\
\hline \multirow[t]{2}{*}{ S\&P ratings } & 0.120 & 0.118 & 0.127 & 0.084 \\
\hline & {$[0.060]^{*}$} & {$[0.063]^{*}$} & {$[0.040]^{* *}$} & {$[0.062]^{*}$} \\
\hline \multirow[t]{2}{*}{ Leverage } & 0.458 & 0.379 & 0.421 & 0.252 \\
\hline & {$[0.060]^{*}$} & {$[0.066]^{*}$} & {$[0.034]^{* *}$} & {$[0.037]^{* *}$} \\
\hline \multirow[t]{2}{*}{ Tangibility } & -0.104 & -0.113 & -0.107 & -0.181 \\
\hline & [0.115] & {$[0.027]^{* *}$} & {$[0.011]^{* *}$} & 0.252 \\
\hline \multirow[t]{2}{*}{$Q$} & -0.098 & -0.101 & -0.105 & -0.106 \\
\hline & {$[0.061]^{*}$} & {$[0.041]^{* *}$} & {$[0.056]^{*}$} & {$[0.049]^{* *}$} \\
\hline \multirow[t]{2}{*}{ Profitability } & -0.763 & -0.781 & -0.759 & -0.715 \\
\hline & [0.123] & {$[0.082]^{*}$} & {$[0.094]^{*}$} & {$[0.025]^{* *}$} \\
\hline \multirow[t]{2}{*}{ Cash-flow volatility } & 0.017 & 0.015 & 0.014 & 0.013 \\
\hline & {$[0.019]^{* *}$} & {$[0.096]^{*}$} & {$[0.062]^{*}$} & {$[0.040]^{* *}$} \\
\hline \multirow[t]{2}{*}{ Performance pricing dummy } & -0.017 & -0.023 & -0.018 & -0.016 \\
\hline & [0.147] & {$[0.059]^{*}$} & [0.118] & [0.142] \\
\hline \multirow[t]{2}{*}{ Term loan dummy } & 0.038 & 0.040 & 0.038 & 0.039 \\
\hline & {$[0.031]^{* *}$} & {$[0.027]^{* *}$} & {$[0.036]^{* *}$} & {$[0.033]^{* *}$} \\
\hline \multirow[t]{2}{*}{ Log loan size } & -0.029 & -0.037 & -0.026 & -0.029 \\
\hline & {$[0.173]$} & {$[0.048]^{* *}$} & {$[0.264]$} & {$[0.010]^{* *}$} \\
\hline \multirow[t]{2}{*}{ Log loan maturity } & 0.078 & 0.074 & 0.079 & 0.074 \\
\hline & {$[0.087]^{*}$} & {$[0.103]$} & {$[0.042]^{* *}$} & {$[0.045]^{* *}$} \\
\hline \multirow[t]{2}{*}{ Sovereign rating } & 0.180 & 0.176 & 0.178 & 0.146 \\
\hline & {$[0.124]$} & {$[0.131]$} & [0.122] & {$[0.042]^{* *}$} \\
\hline \multirow[t]{2}{*}{ Creditor rights } & -0.164 & -0.153 & -0.152 & -0.137 \\
\hline & {$[0.025]^{* *}$} & {$[0.021]^{* *}$} & {$[0.036]^{* *}$} & {$[0.061]^{*}$} \\
\hline \multirow[t]{2}{*}{ Private credit/GDP } & 0.374 & 0.375 & 0.383 & 0.402 \\
\hline & {$[0.124]$} & {$[0.066]^{*}$} & {$[0.022]^{* *}$} & {$[0.041]^{* *}$} \\
\hline \multirow[t]{2}{*}{ Log GDP per capita } & -0.035 & -0.035 & -0.037 & -0.038 \\
\hline & {$[0.175]$} & {$[0.132]$} & {$[0.090]^{*}$} & {$[0.085]^{*}$} \\
\hline Loan purpose dummies & Yes & Yes & Yes & Yes \\
\hline Industry effects & Yes & Yes & Yes & Yes \\
\hline Time effects & Yes & Yes & Yes & Yes \\
\hline Number of observations & 12,593 & 12,593 & 12,593 & 12,593 \\
\hline Number of firms & 3,276 & 3,276 & 3,276 & 3,276 \\
\hline Adjusted $R^{2}$ & 0.235 & 0.232 & 0.234 & 0.235 \\
\hline
\end{tabular}




\section{Table 8}

Borrowing firm credit rating and the effect of the control-ownership wedge on loan pricing

This table presents the regression results on the effect of borrowing firm credit rating on the relation between the control-ownership wedge and loan pricing. The sample consists of bank loans made to firms in 22 Western European and East Asian countries during the period from 1996 to 2008. The dependent variable is the log loan spread. The control-ownership wedge is defined as the difference between the control rights and cash-flow rights of the largest ultimate owner of the firm. Investment-grade dummy equals one if the borrowing firm credit rating is BBB or better and zero otherwise. Definitions of all the other variables are reported in Table 1. $P$-Values based on robust standard errors clustered by firm are reported in brackets. Significance at the $10 \%, 5 \%$, and $1 \%$ level is indicated by *, **, and $* * *$, respectively.

\begin{tabular}{|c|c|c|}
\hline & (1) & (2) \\
\hline \multirow[t]{2}{*}{ Control-ownership wedge } & 1.054 & 1.167 \\
\hline & {$[0.006]^{* * *}$} & {$[0.004]^{* * *}$} \\
\hline \multirow[t]{2}{*}{ S\&P ratings } & 0.124 & \\
\hline & {$[0.017]^{* *}$} & \\
\hline \multirow[t]{2}{*}{ S\&P ratings $x$ Wedge } & 0.487 & \\
\hline & {$[0.003]^{* * *}$} & \\
\hline \multirow[t]{2}{*}{ Investment-grade dummy } & & -0.084 \\
\hline & & {$[0.012]^{* *}$} \\
\hline \multirow[t]{2}{*}{ Investment-grade dummy x Wedge } & & -0.673 \\
\hline & & {$[0.000]^{* * *}$} \\
\hline \multirow[t]{2}{*}{ Cash-flow rights } & -0.378 & -0.374 \\
\hline & {$[0.021]^{* *}$} & {$[0.028]^{* *}$} \\
\hline \multirow[t]{2}{*}{ No rating dummy } & 0.116 & 0.127 \\
\hline & {$[0.097]^{*}$} & {$[0.039]^{* *}$} \\
\hline \multirow[t]{2}{*}{ Leverage } & 0.372 & 0.381 \\
\hline & {$[0.066]^{*}$} & {$[0.062]^{*}$} \\
\hline \multirow[t]{2}{*}{ Tangibility } & -0.119 & -0.116 \\
\hline & {$[0.018]^{* *}$} & {$[0.051]^{*}$} \\
\hline \multirow[t]{2}{*}{ Log assets } & -0.320 & -0.314 \\
\hline & {$[0.039]^{* *}$} & {$[0.040]^{* *}$} \\
\hline \multirow[t]{2}{*}{$Q$} & -0.101 & -0.091 \\
\hline & {$[0.080]^{*}$} & {$[0.136]$} \\
\hline \multirow[t]{2}{*}{ Profitability } & -0.779 & -0.766 \\
\hline & {$[0.089]^{*}$} & {$[0.094]^{*}$} \\
\hline \multirow[t]{2}{*}{ Cash-flow volatility } & 0.015 & 0.017 \\
\hline & [0.126] & {$[0.126]$} \\
\hline
\end{tabular}

(continued on the next page) 
Table 8

Borrowing firm credit rating and the effect of the control-ownership wedge on loan pricing (Continued)

\begin{tabular}{lll}
\hline & \multicolumn{1}{c}{$(1)$} & \multicolumn{1}{c}{$(2)$} \\
\hline Performance pricing dummy & -0.017 & -0.012 \\
Term loan dummy & {$[0.053]^{*}$} & {$[0.160]$} \\
& 0.039 & 0.036 \\
Log loan size & {$[0.031]^{* *}$} & {$[0.029]^{* *}$} \\
& -0.027 & -0.028 \\
Log loan maturity & {$[0.067]^{*}$} & {$[0.072]^{*}$} \\
& 0.071 & 0.073 \\
Sovereign rating & {$[0.062]^{*}$} & {$[0.055]^{*}$} \\
& 0.171 & 0.173 \\
Creditor rights & {$[0.143]$} & {$[0.131]$} \\
Private credit/GDP & -0.152 & -0.151 \\
Log GDP per capita & {$[0.029]^{* *}$} & {$[0.028]^{* *}$} \\
Loan purpose dummies & 0.388 & 0.389 \\
Industry effects & {$[0.122]$} & {$[0.077]^{*}$} \\
Time effects & -0.034 & -0.032 \\
Number of observations & {$[0.068]^{*}$} & {$[0.061]^{*}$} \\
Number of firms & Yes & Yes \\
Adjusted $R^{2}$ & Yes & Yes \\
\hline
\end{tabular}


Table 9

Borrowing firm propping potential and the effect of the control-ownership wedge on loan pricing

This table presents the regression results on the effect of borrowing firm propping potential on the relation between the control-ownership wedge and loan pricing. The sample consists of bank loans made to firms in 22 Western European and East Asian countries during the period from 1996 to 2008. The dependent variable is the log loan spread. The control-ownership wedge is defined as the difference between the control rights and cash-flow rights of the largest ultimate owner of the firm. Propping potential is computed in the first two columns as the total value of the assets of all firms that lie underneath the borrowing firm's position in the pyramid, divided by the borrowing firm's total assets, and in the last two columns as a weighted sum of the values of the assets of all firms that lie underneath the borrowing firm in the pyramid divided by the borrowing firm's total assets, with the weight for each firm lower down in the pyramid beneath the borrower defined as the control rights of the ultimate controlling shareholder on that firm. Definitions of all the other variables are reported in Table 1. $P$-Values based on robust standard errors clustered by firm are reported in brackets. Significance at the $10 \%, 5 \%$, and $1 \%$ level is indicated by $*, * *$, and ${ }^{* * *}$, respectively.

\begin{tabular}{|c|c|c|c|c|}
\hline & (1) & (2) & (3) & (4) \\
\hline \multirow[t]{2}{*}{ Control-ownership wedge } & 1.270 & 1.316 & 1.284 & 1.302 \\
\hline & {$[0.003]^{* * *}$} & {$[0.000]^{* * *}$} & {$[0.002]^{* * *}$} & {$[0.007]^{* * *}$} \\
\hline \multirow[t]{2}{*}{ Propping potential } & -0.104 & -0.108 & -0.583 & -0.522 \\
\hline & {$[0.016]^{* *}$} & {$[0.006]^{* * *}$} & {$[0.027]^{* *}$} & {$[0.011]^{* *}$} \\
\hline \multirow[t]{2}{*}{ Propping potential x Wedge } & & -0.204 & & -1.316 \\
\hline & & {$[0.012]^{* *}$} & & {$[0.002]^{* * *}$} \\
\hline \multirow[t]{2}{*}{ Cash-flow rights } & -0.371 & -0.375 & -0.369 & -0.381 \\
\hline & {$[0.025]^{* *}$} & {$[0.026]^{* *}$} & {$[0.028]^{* *}$} & {$[0.024]^{* *}$} \\
\hline \multirow[t]{2}{*}{ S\&P ratings } & 0.134 & 0.127 & 0.135 & 0.132 \\
\hline & {$[0.032]^{* *}$} & {$[0.076]^{*}$} & [0.069]* & {$[0.073]^{*}$} \\
\hline \multirow[t]{2}{*}{ No rating dummy } & 0.168 & 0.139 & 0.173 & 0.149 \\
\hline & {$[0.082]^{*}$} & {$[0.126]$} & {$[0.034]^{* *}$} & {$[0.116]$} \\
\hline \multirow[t]{2}{*}{ Leverage } & 0.378 & 0.407 & 0.378 & 0.395 \\
\hline & {$[0.066]^{*}$} & {$[0.031]^{* *}$} & {$[0.121]$} & {$[0.063]^{*}$} \\
\hline \multirow[t]{2}{*}{ Tangibility } & -0.115 & -0.11 & -0.114 & -0.115 \\
\hline & {$[0.024]^{* *}$} & {$[0.062]^{*}$} & {$[0.057]^{*}$} & {$[0.023]^{* *}$} \\
\hline \multirow[t]{2}{*}{ Log assets } & -0.293 & -0.307 & -0.312 & -0.308 \\
\hline & {$[0.069]^{*}$} & {$[0.044]^{* *}$} & {$[0.040]^{* *}$} & {$[0.042]^{* *}$} \\
\hline \multirow[t]{2}{*}{$Q$} & -0.088 & -0.085 & -0.084 & -0.086 \\
\hline & {$[0.112]$} & {$[0.123]$} & {$[0.109]$} & {$[0.117]$} \\
\hline \multirow[t]{2}{*}{ Profitability } & -0.740 & -0.730 & -0.742 & -0.736 \\
\hline & {$[0.080]^{*}$} & [0.142] & {$[0.079]^{*}$} & {$[0.084]^{*}$} \\
\hline \multirow[t]{2}{*}{ Cash-flow volatility } & 0.016 & 0.021 & 0.018 & 0.017 \\
\hline & {$[0.146]$} & {$[0.032]^{* *}$} & {$[0.113]$} & {$[0.142]$} \\
\hline
\end{tabular}

(continued on the next page) 
Table 9

Borrowing firm propping potential and the effect of the control-ownership wedge on loan pricing (Continued)

\begin{tabular}{lllll}
\hline & $(1)$ & \multicolumn{1}{c}{$(2)$} & \multicolumn{1}{c}{$(3)$} & \multicolumn{1}{c}{$(4)$} \\
\hline Performance pricing dummy & -0.014 & -0.016 & -0.019 & -0.015 \\
& {$[0.129]$} & {$[0.074]^{*}$} & {$[0.028]^{* *}$} & {$[0.057]^{*}$} \\
Term loan dummy & 0.039 & 0.032 & 0.042 & 0.034 \\
Log loan size & {$[0.065]^{*}$} & {$[0.223]$} & {$[0.035]^{* *}$} & {$[0.218]$} \\
& -0.031 & -0.026 & -0.028 & -0.027 \\
Log loan maturity & {$[0.032]^{* *}$} & {$[0.061]^{*}$} & {$[0.061]^{*}$} & {$[0.064]^{*}$} \\
& 0.070 & 0.072 & 0.073 & 0.069 \\
Sovereign rating & {$[0.051]^{*}$} & {$[0.065]^{*}$} & {$[0.029]^{* *}$} & {$[0.062]^{*}$} \\
Creditor rights & 0.163 & 0.164 & 0.163 & 0.162 \\
Private credit/GDP & {$[0.124]$} & {$[0.123]$} & {$[0.123]$} & {$[0.131]$} \\
& -0.150 & -0.147 & -0.151 & -0.149 \\
Log GDP per capita & {$[0.026]^{* *}$} & {$[0.029]^{* *}$} & {$[0.025]^{* *}$} & {$[0.027]^{* *}$} \\
Loan purpose dummies & 0.420 & 0.322 & 0.381 & 0.329 \\
Industry effects & {$[0.034]^{* *}$} & {$[0.219]$} & {$[0.071]^{*}$} & {$[0.118]$} \\
Time effects & -0.031 & -0.028 & -0.033 & -0.027 \\
Number of observations & {$[0.072]^{*}$} & {$[0.129]$} & {$[0.071]^{*}$} & {$[0.121]$} \\
Number of firms & Yes & Yes & Yes & Yes \\
Adjusted $R^{2}$ & Yes & Yes & Yes & Yes \\
\hline
\end{tabular}




\section{Table 10}

Loan terms and the effect of the control-ownership wedge on loan pricing

This table presents the regression results on the effect of various loan features on the relation between the control-ownership wedge and loan pricing. The sample consists of bank loans made to firms in 22 Western European and East Asian countries during the period from 1996 to 2008. The dependent variable is the log loan spread. The control-ownership wedge is defined as the difference between the control rights and cash-flow rights of the largest ultimate owner of the firm. Bullet loan dummy is a dummy variable that equals one if the loan facility is a bullet loan and zero otherwise. Log loan maturity is the natural log of the loan maturity measured in days. Number of covenants is the total number of covenants for the loan. Collateral dummy is a dummy variable that equals one if the loan facility is secured by collateral and zero otherwise. Definitions of all the other variables are reported in Table 1. P-Values based on robust standard errors clustered by firm are reported in brackets. Significance at the $10 \%, 5 \%$, and $1 \%$ level is indicated by $*$,**, and ${ }^{* * *}$, respectively.

\begin{tabular}{|c|c|c|c|c|}
\hline & (1) & $(2)$ & (3) & (4) \\
\hline \multirow[t]{2}{*}{ Control-ownership wedge } & 1.199 & 1.202 & 1.147 & 1.158 \\
\hline & {$[0.021]^{* *}$} & {$[0.020]^{* *}$} & {$[0.029]^{* *}$} & {$[0.026]^{* *}$} \\
\hline \multirow[t]{2}{*}{ Bullet loan dummy } & 0.146 & & & \\
\hline & {$[0.015]^{* *}$} & & & \\
\hline \multirow[t]{2}{*}{ Bullet loan x Wedge } & 0.287 & & & \\
\hline & {$[0.007]^{* * *}$} & & & \\
\hline \multirow[t]{2}{*}{ Log loan maturity x Wedge } & & 0.655 & & \\
\hline & & {$[0.004]^{* * *}$} & & \\
\hline \multirow[t]{2}{*}{ Number of covenants } & & & -0.036 & \\
\hline & & & {$[0.000]^{* * *}$} & \\
\hline \multirow[t]{2}{*}{ Number of covenants x Wedge } & & & -0.082 & \\
\hline & & & {$[0.007]^{* * *}$} & \\
\hline \multirow[t]{2}{*}{ Collateral dummy } & & & & -0.059 \\
\hline & & & & {$[0.000]^{* * *}$} \\
\hline \multirow[t]{2}{*}{ Collateral x Wedge } & & & & -0.039 \\
\hline & & & & {$[0.014]^{* *}$} \\
\hline \multirow[t]{2}{*}{ Log loan maturity } & 0.071 & 0.077 & 0.089 & 0.088 \\
\hline & {$[0.042]^{* *}$} & {$[0.029]^{* *}$} & {$[0.012]^{* *}$} & {$[0.016]^{* *}$} \\
\hline \multirow[t]{2}{*}{ Cash-flow rights } & -0.391 & -0.334 & -0.342 & -0.358 \\
\hline & {$[0.016]^{* *}$} & {$[0.029]^{* *}$} & {$[0.017]^{* *}$} & {$[0.028]^{* *}$} \\
\hline
\end{tabular}

(continued on the next page) 
Table 10

Loan terms and the effect of the control-ownership wedge on loan pricing (Continued)

\begin{tabular}{|c|c|c|c|c|}
\hline & (1) & $(2)$ & (3) & $(4)$ \\
\hline \multirow[t]{2}{*}{ S\&P ratings } & 0.185 & 0.135 & 0.173 & 0.175 \\
\hline & {$[0.031]^{* *}$} & {$[0.057]^{*}$} & {$[0.064]^{*}$} & {$[0.036]^{* *}$} \\
\hline \multirow[t]{2}{*}{ No rating dummy } & 0.141 & 0.213 & 0.169 & 0.143 \\
\hline & {$[0.095]^{*}$} & {$[0.039]^{* *}$} & {$[0.029]^{* *}$} & {$[0.051]^{*}$} \\
\hline \multirow[t]{2}{*}{ Leverage } & 0.300 & 0.375 & 0.324 & 0.309 \\
\hline & {$[0.068]^{*}$} & {$[0.066]^{*}$} & {$[0.047]^{* *}$} & {$[0.079]^{*}$} \\
\hline \multirow[t]{2}{*}{ Tangibility } & -0.113 & -0.114 & -0.136 & -0.154 \\
\hline & {$[0.024]^{* *}$} & {$[0.011]^{* *}$} & {$[0.078]^{*}$} & {$[0.062]^{*}$} \\
\hline \multirow[t]{2}{*}{ Log assets } & -0.443 & -0.313 & -0.328 & -0.316 \\
\hline & {$[0.033]^{* *}$} & {$[0.036]^{* *}$} & {$[0.031]^{* *}$} & {$[0.037]^{* *}$} \\
\hline \multirow[t]{2}{*}{$Q$} & -0.080 & -0.100 & -0.113 & -0.117 \\
\hline & {$[0.092]^{*}$} & {$[0.041]^{* *}$} & {$[0.094]^{*}$} & {$[0.087]^{*}$} \\
\hline \multirow[t]{2}{*}{ Profitability } & -0.864 & -0.775 & -0.823 & -0.615 \\
\hline & {$[0.038]^{* *}$} & {$[0.089]^{*}$} & {$[0.037]^{* *}$} & {$[0.064]^{*}$} \\
\hline \multirow[t]{2}{*}{ Cash-flow volatility } & 0.018 & 0.014 & 0.019 & 0.011 \\
\hline & {$[0.022]^{* *}$} & {$[0.063]^{*}$} & {$[0.135]$} & {$[0.072]^{*}$} \\
\hline \multirow[t]{2}{*}{ Performance pricing dummy } & -0.019 & -0.018 & 0.016 & 0.017 \\
\hline & {$[0.155]$} & {$[0.061]^{*}$} & {$[0.037]^{* *}$} & {$[0.052]^{*}$} \\
\hline \multirow[t]{2}{*}{ Term loan dummy } & 0.027 & 0.038 & 0.037 & 0.041 \\
\hline & {$[0.036]^{* *}$} & {$[0.020]^{* *}$} & {$[0.024]^{* *}$} & {$[0.019]^{* *}$} \\
\hline \multirow[t]{2}{*}{ Log loan size } & -0.026 & -0.029 & -0.027 & -0.031 \\
\hline & {$[0.177]$} & {$[0.036]^{* *}$} & {$[0.031]^{* *}$} & {$[0.039]^{* *}$} \\
\hline \multirow[t]{2}{*}{ Sovereign risk rating } & 0.105 & 0.180 & 0.156 & 0.139 \\
\hline & {$[0.208]$} & {$[0.117]$} & {$[0.038]^{* *}$} & {$[0.067]^{*}$} \\
\hline \multirow[t]{2}{*}{ Creditor rights } & -0.174 & -0.152 & -0.179 & -0.186 \\
\hline & {$[0.036]^{* *}$} & {$[0.026]^{* *}$} & {$[0.023]^{* *}$} & {$[0.029]^{* *}$} \\
\hline \multirow[t]{2}{*}{ Private credit to GDP } & 0.345 & 0.390 & 0.362 & 0.287 \\
\hline & {$[0.172]$} & {$[0.040]^{* *}$} & {$[0.087]^{*}$} & {$[0.039]^{* *}$} \\
\hline \multirow[t]{2}{*}{ Log GDP per capita } & -0.023 & -0.035 & -0.024 & -0.028 \\
\hline & {$[0.060]^{*}$} & {$[0.432]$} & {$[0.037]^{* *}$} & {$[0.076]^{*}$} \\
\hline Loan purpose dummies & Yes & Yes & Yes & Yes \\
\hline Industry effects & Yes & Yes & Yes & Yes \\
\hline Time effects & Yes & Yes & Yes & Yes \\
\hline Number of observations & 12,593 & 12,593 & 12,593 & 12,593 \\
\hline Number of firms & 3,276 & 3,276 & 3,276 & 3,276 \\
\hline Adjusted $R^{2}$ & 0.271 & 0.234 & 0.231 & 0.246 \\
\hline
\end{tabular}




\section{Table 11}

Legal rights, debt enforcement efficiency, and the effect of the control-ownership wedge on loan pricing

This table presents the regression results on the effect of creditor rights and shareholder rights on the relation between the control-ownership wedge and loan pricing. The sample consists of bank loans made to firms in 22 Western European and East Asian countries during the period from 1996 to 2008. The dependent variable is the log loan spread. The control-ownership wedge is defined as the difference between the control rights and cash-flow rights of the largest ultimate owner of the firm. The creditor rights variable is an index aggregating creditor rights (La Porta et al., 1998; Djankov et al., 2007) ranging from zero to four, with higher values indicating stronger creditor rights. Anti-self-dealing is an index compiled by Djankov et al. (2008b), with higher values indicating better protection of investors against self-dealing by controlling shareholders. Anti-director is an index compiled by La Porta et al. (1998) and Djankov et al. (2008b) ranging from zero to six, with higher values indicating stronger investor protection against insider expropriation. Time to payment is the estimated number of years from the moment of a firm's default to the time when the secured creditor gets paid in each country (Djankov et al., 2008a). Cost of debt enforcement is the estimated cost of the insolvency proceeding borne by all parties divided by the value of the insolvency estate in each country (Djankov et al., 2008a). Definitions of all the other variables are reported in Table 1. $P$-Values based on robust standard errors clustered by firm are reported in brackets. Significance at the $10 \%, 5 \%$, and $1 \%$ level is indicated by $*$, ${ }^{* *}$, and $* * *$, respectively.

\begin{tabular}{|c|c|c|c|c|c|}
\hline & (1) & (2) & (3) & (4) & (5) \\
\hline \multirow[t]{2}{*}{ Control-ownership wedge } & 1.242 & 1.231 & 1.227 & 1.411 & 1.304 \\
\hline & {$[0.006]^{* * *}$} & {$[0.004]^{* * *}$} & {$[0.031]^{* *}$} & {$[0.018]^{* *}$} & {$[0.002]^{* * *}$} \\
\hline \multirow[t]{2}{*}{ Creditor rights } & -0.280 & -0.318 & -0.335 & -0.236 & -0.172 \\
\hline & {$[0.005]^{* * *}$} & {$[0.032]^{* *}$} & {$[0.029]^{* *}$} & {$[0.034]^{* *}$} & {$[0.039]^{* *}$} \\
\hline \multirow[t]{2}{*}{ Creditor rights x Wedge } & -0.242 & & & & \\
\hline & {$[0.002]^{* * *}$} & & & & \\
\hline \multirow[t]{2}{*}{ Anti-self-dealing } & & -0.293 & & & \\
\hline & & {$[0.016]^{* *}$} & & & \\
\hline \multirow[t]{2}{*}{ Anti-self-dealing x Wedge } & & -0.742 & & & \\
\hline & & {$[0.003]^{* * *}$} & & & \\
\hline \multirow[t]{2}{*}{ Anti-director } & & & -0.082 & & \\
\hline & & & {$[0.024]^{* *}$} & & \\
\hline \multirow[t]{2}{*}{ Anti-director x Wedge } & & & -0.202 & & \\
\hline & & & {$[0.011]^{* *}$} & & \\
\hline \multirow[t]{2}{*}{ Time to payment } & & & & 0.073 & \\
\hline & & & & {$[0.006]^{* * *}$} & \\
\hline \multirow[t]{2}{*}{ Time to payment $\mathrm{x}$ Wedge } & & & & 0.155 & \\
\hline & & & & {$[0.012]^{* *}$} & \\
\hline \multirow[t]{2}{*}{ Cost of enforcement } & & & & & 0.019 \\
\hline & & & & & {$[0.027]^{* *}$} \\
\hline \multirow[t]{2}{*}{ Cost of enforcement x Wedge } & & & & & 0.289 \\
\hline & & & & & {$[0.034]^{* *}$} \\
\hline \multirow[t]{2}{*}{ Cash-flow rights } & -0.450 & -0.404 & -0.400 & -0.370 & -0.401 \\
\hline & {$[0.031]^{* *}$} & {$[0.033]^{* *}$} & {$[0.033]^{* *}$} & {$[0.026]^{* *}$} & {$[0.032]^{* *}$} \\
\hline
\end{tabular}

(continued on the next page) 


\section{Table 11}

Legal rights, debt enforcement efficiency, and the effect of the control-ownership wedge on loan pricing (Continued)

\begin{tabular}{|c|c|c|c|c|c|}
\hline & (1) & (2) & (3) & (4) & (5) \\
\hline \multirow[t]{2}{*}{ S\&P ratings } & 0.107 & 0.100 & 0.089 & 0.104 & 0.106 \\
\hline & {$[0.067]^{*}$} & {$[0.057]^{*}$} & {$[0.043]^{* *}$} & {$[0.063]^{*}$} & {$[0.045]^{* *}$} \\
\hline \multirow[t]{2}{*}{ No rating dummy } & 0.157 & 0.173 & 0.214 & 0.129 & 0.145 \\
\hline & {$[0.086]^{*}$} & {$[0.091]^{*}$} & [0.059]* & {$[0.094]^{*}$} & {$[0.270]$} \\
\hline \multirow[t]{2}{*}{ Leverage } & 0.270 & 0.257 & 0.210 & 0.289 & 0.275 \\
\hline & {$[0.064]^{*}$} & {$[0.096]^{*}$} & {$[0.046]^{* *}$} & {$[0.157]$} & {$[0.062]^{*}$} \\
\hline \multirow[t]{2}{*}{ Tangibility } & -0.109 & -0.114 & -0.116 & -0.103 & -0.104 \\
\hline & {$[0.027]^{* *}$} & {$[0.070]^{*}$} & {$[0.142]$} & {$[0.031]^{* *}$} & {$[0.216]$} \\
\hline \multirow[t]{2}{*}{ Log assets } & -0.315 & -0.321 & -0.328 & -0.312 & -0.314 \\
\hline & {$[0.037]^{* *}$} & {$[0.089]^{*}$} & {$[0.026]^{* *}$} & {$[0.057]^{*}$} & {$[0.162]^{*}$} \\
\hline \multirow[t]{2}{*}{$Q$} & -0.101 & -0.100 & -0.118 & -0.105 & -0.104 \\
\hline & {$[0.154]$} & {$[0.015]^{* *}$} & {$[0.108]$} & {$[0.327]$} & {$[0.451]$} \\
\hline \multirow[t]{2}{*}{ Profitability } & -0.769 & -0.768 & -0.716 & -0.674 & -0.737 \\
\hline & {$[0.182]$} & {$[0.027]^{* *}$} & {$[0.066]^{*}$} & {$[0.142]$} & {$[0.086]^{*}$} \\
\hline \multirow[t]{2}{*}{ Cash-flow volatility } & 0.014 & 0.014 & 0.014 & 0.017 & 0.012 \\
\hline & {$[0.063]^{*}$} & {$[0.092]^{*}$} & {$[0.173]$} & {$[0.053]^{*}$} & {$[0.346]$} \\
\hline \multirow[t]{2}{*}{ Performance pricing dummy } & -0.018 & -0.019 & -0.018 & -0.014 & -0.017 \\
\hline & {$[0.057]^{*}$} & {$[0.030]^{* *}$} & {$[0.021]^{* *}$} & {$[0.261]$} & {$[0.082]^{*}$} \\
\hline \multirow[t]{2}{*}{ Term loan dummy } & 0.037 & 0.039 & 0.040 & 0.036 & 0.034 \\
\hline & {$[0.035]^{* *}$} & {$[0.078]^{*}$} & [0.152] & {$[0.141]$} & {$[0.082]^{*}$} \\
\hline \multirow[t]{2}{*}{ Log loan size } & -0.029 & -0.029 & -0.033 & -0.031 & -0.027 \\
\hline & {$[0.073]^{*}$} & {$[0.062]^{*}$} & {$[0.024]^{* *}$} & {$[0.062]^{*}$} & {$[0.064]^{*}$} \\
\hline \multirow[t]{2}{*}{ Log loan maturity } & 0.074 & 0.075 & 0.076 & 0.089 & 0.091 \\
\hline & {$[0.029]^{* *}$} & {$[0.019]^{* *}$} & {$[0.032]^{* *}$} & {$[0.031]^{* *}$} & {$[0.025]^{* *}$} \\
\hline \multirow[t]{2}{*}{ Sovereign risk rating } & 0.168 & 0.185 & 0.164 & 0.143 & 0.139 \\
\hline & {$[0.132]$} & {$[0.141]$} & {$[0.163]$} & {$[0.127]$} & {$[0.118]$} \\
\hline \multirow[t]{2}{*}{ Private credit to GDP } & 0.389 & 0.385 & 0.352 & 0.358 & 0.365 \\
\hline & {$[0.021]^{* *}$} & {$[0.078]^{*}$} & {$[0.027]^{* *}$} & {$[0.036]^{* *}$} & {$[0.141]$} \\
\hline \multirow[t]{2}{*}{ Log GDP per capita } & -0.035 & -0.035 & -0.033 & -0.026 & -0.034 \\
\hline & {$[0.142]$} & {$[0.028]^{* *}$} & {$[0.025]^{* *}$} & {$[0.176]$} & {$[0.058]^{*}$} \\
\hline Loan purpose dummies & Yes & Yes & Yes & Yes & Yes \\
\hline Industry effects & Yes & Yes & Yes & Yes & Yes \\
\hline Time effects & Yes & Yes & Yes & Yes & Yes \\
\hline Number of observations & 12,593 & 12,593 & 12,593 & 12,593 & 12,593 \\
\hline Number of firms & 3,276 & 3,276 & 3,276 & 3,276 & 3,276 \\
\hline Adjusted $R^{2}$ & 0.232 & 0.242 & 0.237 & 0.261 & 0.253 \\
\hline
\end{tabular}


Table 12

Financial crises and the effect of the control-ownership wedge on loan pricing

This table presents the regression results on the effect of financial crises on the relation between the control-ownership wedge and loan pricing. The sample consists of bank loans made to firms in 22 Western European and East Asian countries during the period from 1996 to 2008. The dependent variable is the log loan spread. The control-ownership wedge is defined as the difference between the control rights and cash-flow rights of the largest ultimate owner of the firm. Financial crisis dummy equals one if the country is going through a financial crisis in the observation year and zero if it is not, defined according to the Banking Crisis Database, compiled by IMF economists (Honohan and Laeven, 2005; Laeven and Valencia, 2008). Definitions of all the other variables are reported in Table 1. $P$-Values based on robust standard errors clustered by firm are reported in brackets. Significance at the $10 \%, 5 \%$, and $1 \%$ level is indicated by $* * *$, and $* * *$, respectively.

\begin{tabular}{|c|c|c|c|c|c|}
\hline & $(1)$ & $(2)$ & (3) & $(4)$ & $(5)$ \\
\hline \multirow[t]{2}{*}{ Control-ownership wedge } & 1.184 & 1.117 & 1.190 & 1.116 & 1.157 \\
\hline & {$[0.008]^{* * *}$} & {$[0.013]^{* *}$} & {$[0.023]^{* *}$} & {$[0.006]^{* * *}$} & {$[0.035]^{* *}$} \\
\hline \multirow[t]{2}{*}{ Financial crisis dummy } & 0.116 & 0.122 & 0.104 & 0.108 & 0.135 \\
\hline & {$[0.003]^{* * *}$} & {$[0.039]^{* *}$} & {$[0.024]^{* *}$} & {$[0.030]^{* *}$} & {$[0.007]^{* * *}$} \\
\hline \multirow[t]{2}{*}{ Financial crisis $x$ Wedge } & & 0.472 & 0.561 & 0.468 & 0.666 \\
\hline & & {$[0.002]^{* * *}$} & {$[0.029]^{* *}$} & {$[0.028]^{* *}$} & {$[0.026]^{* *}$} \\
\hline \multirow[t]{2}{*}{ Creditor rights $\mathrm{x}$ Financial crisis } & & & -0.063 & & \\
\hline & & & {$[0.012]^{* *}$} & & \\
\hline \multirow[t]{2}{*}{ Creditor rights x Wedge } & & & -0.240 & & \\
\hline & & & {$[0.005]^{* * *}$} & & \\
\hline \multirow[t]{2}{*}{ Creditor rights x Financial crisis x Wedge } & & & -0.125 & & \\
\hline & & & {$[0.026]^{* *}$} & & \\
\hline \multirow[t]{2}{*}{ Anti-self-dealing } & & & & -0.263 & \\
\hline & & & & {$[0.027]^{* *}$} & \\
\hline \multirow[t]{2}{*}{ Anti-self-dealing x Financial crisis } & & & & -0.156 & \\
\hline & & & & {$[0.007]^{* * *}$} & \\
\hline \multirow[t]{2}{*}{ Anti-self-dealing x Wedge } & & & & -0.820 & \\
\hline & & & & {$[0.005]^{* * *}$} & \\
\hline \multirow[t]{2}{*}{ Anti-self-dealing x Financial crisis x Wedge } & & & & -0.649 & \\
\hline & & & & {$[0.028]^{* *}$} & \\
\hline \multirow[t]{2}{*}{ Anti-director } & & & & & -0.083 \\
\hline & & & & & {$[0.023]^{* *}$} \\
\hline \multirow[t]{2}{*}{ Anti-director x Financial crisis } & & & & & -0.072 \\
\hline & & & & & {$[0.031]^{* *}$} \\
\hline \multirow[t]{2}{*}{ Anti-director x Wedge } & & & & & -0.273 \\
\hline & & & & & {$[0.034]^{* *}$} \\
\hline \multirow[t]{2}{*}{ Anti-director x Financial crisis x Wedge } & & & & & -0.223 \\
\hline & & & & & {$[0.036]^{* *}$} \\
\hline \multirow[t]{2}{*}{ Creditor rights } & -0.153 & -0.155 & -0.185 & -0.135 & -0.189 \\
\hline & {$[0.023]^{* * *}$} & {$[0.027]^{* *}$} & {$[0.022]^{* *}$} & {$[0.017]^{* *}$} & {$[0.044]^{* *}$} \\
\hline \multirow[t]{2}{*}{ Cash-flow rights } & -0.347 & -0.349 & -0.334 & -0.338 & -0.339 \\
\hline & {$[0.034]^{* *}$} & {$[0.016]^{* *}$} & {$[0.033]^{* *}$} & {$[0.042]^{* *}$} & {$[0.045]^{* *}$} \\
\hline
\end{tabular}

(continued on the next page) 
Table 12

Financial crises and the effect of the control-ownership wedge on loan pricing (Continued)

\begin{tabular}{|c|c|c|c|c|c|}
\hline & (1) & (2) & (3) & (4) & (5) \\
\hline \multirow[t]{2}{*}{ S\&P ratings } & 0.127 & 0.175 & 0.118 & 0.151 & 0.106 \\
\hline & {$[0.060]^{*}$} & {$[0.037]^{* *}$} & {$[0.187]$} & {$[0.178]$} & {$[0.094]^{*}$} \\
\hline \multirow[t]{2}{*}{ No rating dummy } & 0.143 & 0.161 & 0.126 & 0.107 & 0.144 \\
\hline & {$[0.094]^{*}$} & [0.113] & {$[0.031]^{* *}$} & {$[0.128]$} & {$[0.030]^{* *}$} \\
\hline \multirow[t]{2}{*}{ Leverage } & 0.405 & 0.386 & 0.499 & 0.359 & 0.445 \\
\hline & {$[0.065]^{*}$} & {$[0.065]^{*}$} & {$[0.060]^{*}$} & {$[0.038]^{* *}$} & {$[0.063]^{*}$} \\
\hline \multirow[t]{2}{*}{ Tangibility } & -0.111 & -0.113 & -0.093 & -0.078 & -0.100 \\
\hline & {$[0.011]^{* *}$} & {$[0.017]^{* *}$} & {$[0.013]^{* *}$} & {$[0.014]^{* *}$} & {$[0.012]^{* *}$} \\
\hline \multirow[t]{2}{*}{ Log assets } & -0.320 & -0.319 & -0.299 & -0.294 & -0.316 \\
\hline & {$[0.038]^{* *}$} & {$[0.067]^{*}$} & {$[0.062]^{*}$} & {$[0.041]^{* *}$} & {$[0.037]^{* *}$} \\
\hline \multirow[t]{2}{*}{$Q$} & -0.100 & -0.107 & -0.114 & -0.098 & -0.103 \\
\hline & {$[0.060]^{*}$} & [0.155] & {$[0.032]^{* *}$} & {$[0.151]$} & {$[0.057]^{*}$} \\
\hline \multirow[t]{2}{*}{ Profitability } & -0.784 & -0.825 & -0.754 & -0.763 & -0.803 \\
\hline & {$[0.190]$} & {$[0.040]^{* *}$} & {$[0.093]^{*}$} & [0.119] & {$[0.091]^{*}$} \\
\hline \multirow[t]{2}{*}{ Cash-flow volatility } & 0.015 & 0.014 & 0.014 & 0.015 & 0.014 \\
\hline & {$[0.024]^{* *}$} & {$[0.121]$} & {$[0.034]^{* *}$} & {$[0.126]$} & {$[0.081]^{*}$} \\
\hline \multirow[t]{2}{*}{ Performance pricing dummy } & -0.017 & -0.016 & -0.017 & -0.019 & -0.018 \\
\hline & {$[0.165]$} & {$[0.167]$} & {$[0.082]^{*}$} & {$[0.035]^{* *}$} & {$[0.076]^{*}$} \\
\hline \multirow[t]{2}{*}{ Term loan dummy } & 0.039 & 0.037 & 0.040 & 0.037 & 0.038 \\
\hline & {$[0.032]^{* *}$} & {$[0.034]^{* *}$} & {$[0.038]^{* *}$} & {$[0.036]^{* *}$} & {$[0.030]^{* *}$} \\
\hline \multirow[t]{2}{*}{ Log loan size } & -0.029 & -0.03 & -0.029 & -0.029 & -0.029 \\
\hline & {$[0.084]^{*}$} & {$[0.142]$} & {$[0.159]$} & [0.179] & {$[0.171]$} \\
\hline \multirow[t]{2}{*}{ Log loan maturity } & 0.074 & 0.073 & 0.076 & 0.075 & 0.074 \\
\hline & {$[0.125]$} & {$[0.195]$} & {$[0.040]^{* *}$} & {$[0.087]^{*}$} & {$[0.190]$} \\
\hline \multirow[t]{2}{*}{ Sovereign risk rating } & 0.173 & 0.178 & 0.136 & 0.129 & 0.187 \\
\hline & {$[0.126]$} & {$[0.120]$} & {$[0.196]$} & {$[0.208]$} & {$[0.128]$} \\
\hline \multirow[t]{2}{*}{ Private credit to GDP } & 0.384 & 0.393 & 0.409 & 0.374 & 0.404 \\
\hline & {$[0.021]^{* *}$} & {$[0.142]$} & {$[0.195]$} & {$[0.028]^{* *}$} & {$[0.084]^{*}$} \\
\hline \multirow[t]{2}{*}{ Log GDP per capita } & -0.036 & -0.032 & -0.034 & -0.033 & -0.031 \\
\hline & {$[0.157]$} & {$[0.089]^{*}$} & {$[0.151]$} & {$[0.041]^{* *}$} & {$[0.081]^{*}$} \\
\hline Loan purpose dummies & Yes & Yes & Yes & Yes & Yes \\
\hline Industry effects & Yes & Yes & Yes & Yes & Yes \\
\hline Time effects & Yes & Yes & Yes & Yes & Yes \\
\hline Number of observations & 12,593 & 12,593 & 12,593 & 12,593 & 12,593 \\
\hline Number of firms & 3,276 & 3,276 & 3,276 & 3,276 & 3,276 \\
\hline Adjusted $R^{2}$ & 0.232 & 0.235 & 0.234 & 0.238 & 0.236 \\
\hline
\end{tabular}

